NIST Special Publication 1233

\title{
NIST Nanotechnology Environmental, Health, and Safety Research Program: 2009-2016
}

\author{
Debra L. Kaiser \\ Vincent A. Hackley
}

This publication is available free of charge from:

https://doi.org/10.6028/NIST.SP.1233

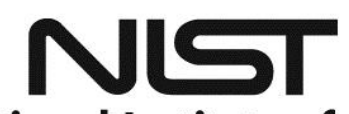

National Institute of Standards and Technology U.S. Department of Commerce 
NIST Special Publication 1233

\title{
NIST Nanotechnology Environmental, Health, and Safety Research Program: 2009-2016
}

\author{
Debra L. Kaiser \\ Office of Data and Informatics \\ Material Measurement Laboratory \\ Vincent A. Hackley \\ Materials Measurement Science Division \\ Material Measurement Laboratory
}

This publication is available free of charge from:

https://doi.org/10.6028/NIST.SP.1233

November 2018

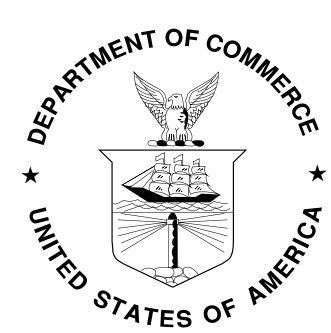

U.S. Department of Commerce Wilbur L. Ross, Jr., Secretary

National Institute of Standards and Technology Walter Copan, NIST Director and Under Secretary of Commerce for Standards and Technology 
Certain commercial entities, equipment, or materials may be identified in this document in order to describe an experimental procedure or concept adequately. Such identification is not intended to imply recommendation or endorsement by the National Institute of Standards and Technology, nor is it intended to imply that the entities, materials, or equipment are necessarily the best available for the purpose.

National Institute of Standards and Technology Special Publication 1233 Natl. Inst. Stand. Technol. Spec. Publ. 1233, 55 pages (November 2018) CODEN: NSPUE2

This publication is available free of charge from: https://doi.org/10.6028/NIST.SP.1233 


\begin{abstract}
In response to needs of a government-wide initiative in nanotechnology led by a subcommittee within the White House's Office of Science and Technology Policy, NIST established a nanotechnology environmental, health, and safety (nano-EHS) research program in 2009 that remained active through 2016. This document summarizes the NIST Nano-EHS Program goals, projects, outputs, and impacts. The program was designed to address, in collaboration with other agencies, the research needs for a comprehensive U.S. measurement infrastructure for nano-EHS as identified by federal agencies participating in the National Nanotechnology Initiative. Such an infrastructure included a suite of measurement tools - methods, protocols, standards (reference materials and documentary), instruments, models, and benchmark (validated) data. The NIST Nano-EHS Program made substantial progress in developing the required infrastructure, producing 9 reference materials, 24 web-accessible protocols, and 212 archival journal articles, $59 \%$ of which have been published in journals with impact factors greater than 3 . In addition, program team members held leadership positions in the nanotechnology committees of major standards development organizations and led and contributed to the development of standards in these committees.
\end{abstract}




\section{Table of Contents}

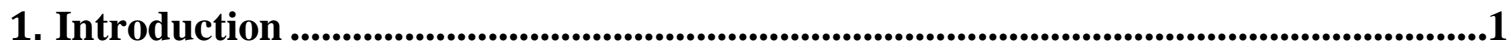

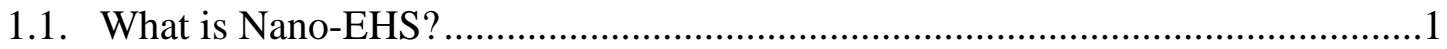

1.2. The National Nanotechnology Initiative and Nano-EHS ..................................

1.3. The NIST Role in Federal Nano-EHS Efforts .................................................2

2. History of the NIST Nano-EHS Program ................................................................2

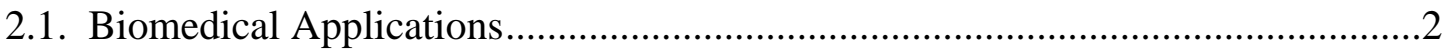

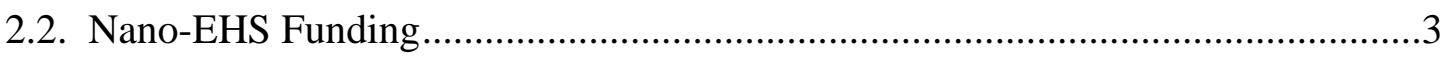

2.3. Nano-EHS Program Researchers .............................................................. 3

3. NIST Nano-EHS Program Goals and Projects .....................................................4

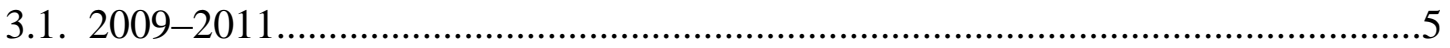

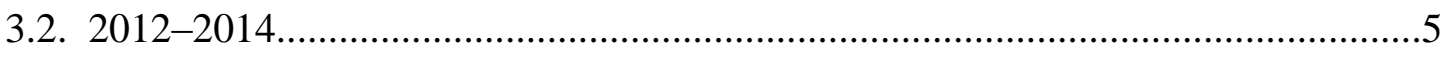

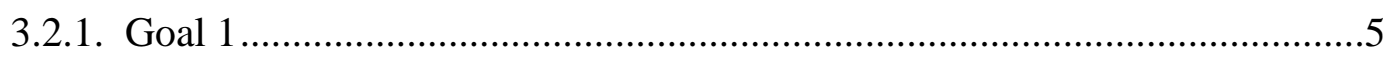

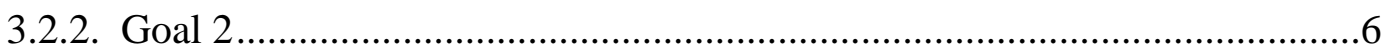

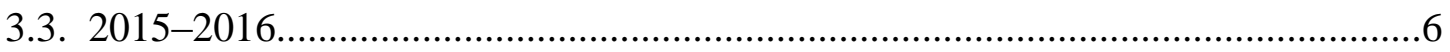

4. NIST Nano-EHS Program Outputs .......................................................................7

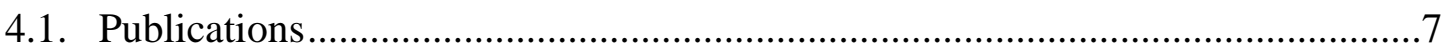

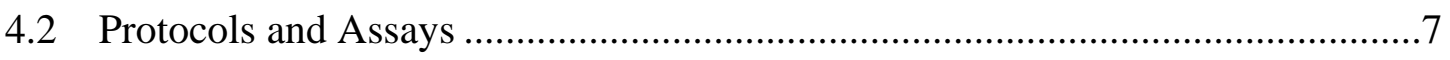

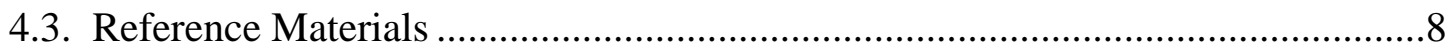

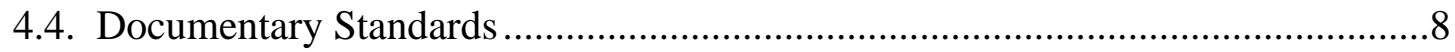

5. NIST Nano-EHS Program Impacts.......................................................................................99

5.1. Case Study I: Gold Nanoparticle Reference Materials ..................................... 9

5.2. Case Study II: Measurement Assurance for a Nanotoxicity Assay ......................10

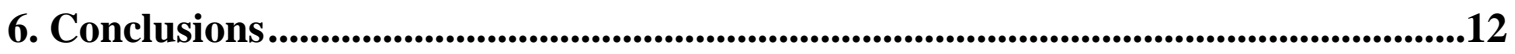

Acknowledgements ...............................................................................................................13

References ..........................................................................................................................13

Appendix A: Nano-EHS Program Researchers ..............................................................15

Appendix B: Nano-EHS Initiative Program Plan, FY12-14 .........................................17

Appendix C: Nano-EHS Program Publications....................................................................23

Appendix D: Nano-EHS Program Protocols and Assays ..............................................45

Appendix E: Nanoscale Reference Materials ..................................................................49 


\section{List of Tables}

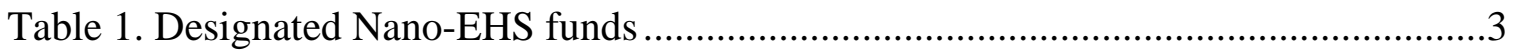

Table 2. Nano-EHS investments reported to the NNI ..............................................

Table 3. Number of publications per JIF range ..........................................................

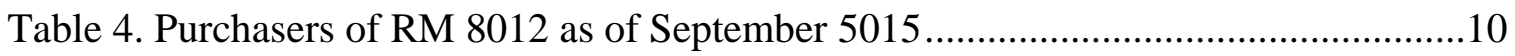

\section{List of Figures}

Fig. 1. Interrelationships of the five core research areas ...........................................2

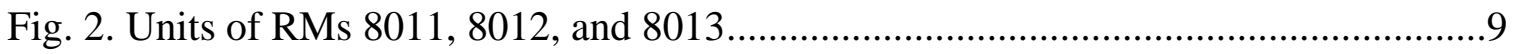

Fig. 3. Number of publications by year ........................................................................ 10

Fig. 4. 96-well plate layout for cytotoxicity assays on ENMs ......................................11 


\section{Introduction}

\subsection{What is Nano-EHS?}

Nano-EHS is a shorthand term for nanotechnology-related environmental, health, and safety issues, which may determine the potential risks of engineered nanomaterials $(\text { ENMs })^{1}$ and nanotechnology-enabled products (NEPs) ${ }^{2}$ to the environment and to humans. Nanotechnology has already led to new and improved products and remains poised to further "transform production processes and consumer products for everything from traditionally high-tech products like computers to less obvious sources of innovation and growth like sunscreen and paint" [1]. Potential nano-EHS risks must be identified, assessed, and managed to enable widespread commercialization and adoption of ENMs and NEPs. Knowledge of such risks to workers, the public, and the environment will enable appropriate regulatory measures to be established, thus alleviating consumer concerns and spurring development and manufacturing of ENMs and NEPs. To perform science-based assessment and management of nano-EHS risks, industry and regulatory agencies need access to and the means to generate accurate and reproducible data on properties, exposure, and hazards of ENMs and NEPs.

\subsection{The National Nanotechnology Initiative and Nano-EHS}

The use of nanomaterials in art dates to the $4^{\text {th }}$ century BC [2] and there are numerous examples of nanotechnology innovations dating from the mid-to-late 1900's, such as the scanning tunneling microscope that enabled single atom imaging, the semiconductor transistor that is the basis of integrated circuits, and the discovery of novel nanomaterials including carbon nanotubes and quantum dots. In 2000, President Clinton launched the National Nanotechnology Initiative (NNI) to coordinate Federal agency nanotechnology efforts and to spur U.S competitiveness in nanotechnology, which led to the rapid promulgation of the term 'nanotechnology'. Three years later, Congress enacted the $21^{\text {st }}$ Century Nanotechnology Research and Development Act [3], which established the statutory foundation for the NNI. The first NNI Strategic Plan [4], written by NNI Federal agency representatives to the Nanoscale Science, Engineering, and Technology Subcommittee (NSET) of the National Science and Technology Council's Committee on Technology, was published in 2004. One of the Plan's four goals was to Support the Responsible Development of Nanotechnology, which largely concerned nano-EHS issues. In addition, the formation of a Nanotechnology Environmental and Health Implications (NEHI) Working Group consisting of Federal agency representatives was mandated in this Strategic Plan. The criticality of addressing EHS issues led to the 2006 publication of a document addressing nano-EHS research needs [5]. Subsequently, strategies for nano-EHS research in the Federal government were published in 2008 [6] and 2011 [7]. The NEHI Working Group developed all three of these documents, and NIST staff members have played an active and leading role in the NEHI Working Group since its inception. In addition, NIST led the development of a 2014 report [8] documenting the

\footnotetext{
${ }^{1}$ Engineered nanomaterials (ENMs) are materials that have been purposely synthesized or manufactured to have at least one external dimension of approximately 1 to 100 nanometers (nm) — at the nanoscale — and that exhibit unique properties determined by this size. [7]

${ }^{2}$ Nanotechnology-enabled products (NEPs) are intermediate engineered nanoscale products, including

ENMs embedded in a matrix material, that exist during manufacture and in final products. [7]
} 
accomplishments and coordination of the NNI-NEHI agencies in response to the needs called out in the 2011 strategy document.

\subsection{The NIST Role in Federal Nano-EHS Efforts}

Figure 1 illustrates the inter-relationships and synergies of the six core research categories in the 2011 nano-EHS research strategy. The product of exposure and hazard is a measure of the risks of ENMs to humans and the environment. Quantifying risk requires accurate and reproducible measurements, which are central to the Nanomaterial Measurement Infrastructure (NMI) research category. The NMI consists of a "suite of complementary tools for accurate, precise, and reproducible measurements [that] is critical for reliable assessment of exposure and hazards for humans and the environment across all life cycle stages of...ENMs and...NEPs" [1]. The NMI is foundational because of the role "measurement tools play in supporting and enabling the research needs in the other research categories" [1]. Measurement tools are defined as methods, protocols, standards (reference material and documentary),

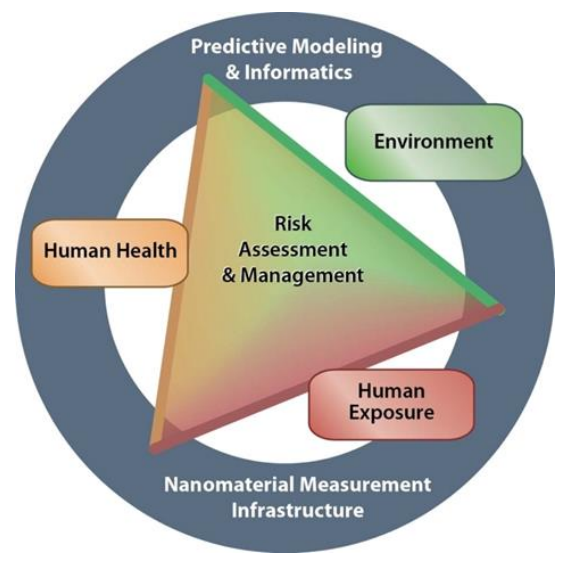

Fig 1. Interrelationships of the six core research areas instruments, models, and benchmark (validated) data. The goals of the NMI core research area are two-fold:

(1) Develop measurement tools to detect and identify engineered nanoscale materials in products and relevant matrices and determine their physico-chemical properties throughout all stages of their life cycles

(2) Develop measurement tools for determination of biological response, and to enable assessment of hazards and exposure for humans and the environment from ENMs and NEPs throughout all stages of their life cycles.

NIST is the lead agency for the NMI research category. As described in subsequent sections of this report, the NIST Nano-EHS Program was well-aligned with the NMI goals.

\section{History of the NIST Nano-EHS Program}

\subsection{Biomedical Applications}

Four years prior to the establishment of the NIST Nano-EHS Program, a NIST-wide effort in nanomaterial metrology and standards was initiated, with a focus on nanoparticles for cancer therapeutics. In 2005, the National Cancer Institute (NCI) established the Nanotechnology Characterization Laboratory (NCL) [9], the activities of which represent a formal scientific partnership between the NCI, the Food and Drug Administration (FDA), and NIST. The NCL's mission is to "perform and standardize the pre-clinical characterization of nanomaterials intended for cancer therapeutics and diagnostics... and facilitate the development and translation of nanoscale particles and devices for clinical applications" [9]. The NCI awarded NIST \$1.0 M/y for three years to develop quantitative, reproducible measurement methods and protocols for nanoparticle 
characterization and to collaborate with NCI and FDA researchers to determine the best measurement tools, protocols, and analysis methods for physically characterizing nanoparticles. One key output of the partnership was the production of three gold nanoparticle reference materials (RMs) with nominal diameters of $10 \mathrm{~nm}$ [10], $30 \mathrm{~nm}$ [11], and $60 \mathrm{~nm}$ [12]. These nanoscale RMs, formally requested by the Office of the Director of NCI, were the first of their kind appropriate for biomedical-related studies and applications. As a direct result of the gold nanoparticle RM project, NIST gained critical expertise and established core capabilities across a broad range of ENM property measurements, including quantitative analysis of nanomaterial size using six independent measurement techniques. This expertise and associated capabilities provided the initial foundation on which the NIST Nano-EHS Program was built, and established NIST internationally as a leader in nanomaterial metrology.

\subsection{Nano-EHS Funding}

Formal NIST-wide programs are typically established with new, federally appropriated "Initiative" funds that are designated for a specific topic. Such funds are a common means of increasing the NIST Scientific and Technical Research and Services (STRS) budget. After five years, Initiative funds become general undesignated STRS funds. The Program received funds from two Initiatives: Nano-EHS in 2009 and Nanomanufacturing in 2012. Additional one-year funds were received from the NIST Director in 2010 and 2011. These designated funds are summarized in Table 1. Many of the Divisions involved in the Program supplemented their nano-EHS activities with their own STRS funds; these funds are not included in Table 1.

Table 1. Designated Nano-EHS funds

\begin{tabular}{|l|l|l|l|l|l|l|l|l|}
\cline { 2 - 10 } \multicolumn{1}{c|}{} & \multicolumn{7}{c|}{ Funds by Fiscal Year, \$ M } \\
\hline Source of Funds & $\mathbf{2 0 0 9}$ & $\mathbf{2 0 1 0}$ & $\mathbf{2 0 1 1}$ & $\mathbf{2 0 1 2}$ & $\mathbf{2 0 1 3}$ & $\mathbf{2 0 1 4}$ & $\mathbf{2 0 1 5}$ & $\mathbf{2 0 1 6}$ \\
\hline Nano-EHS Initiative & 1.8 & 1.8 & 1.8 & 1.8 & 1.8 & & & \\
\hline NIST Director & & 1.0 & 1.0 & & & & & \\
\hline $\begin{array}{l}\text { Nanomanufacturing } \\
\text { Initiative }\end{array}$ & & & & 2.0 & 2.0 & 2.0 & 2.0 & 2.0 \\
\hline Total funds & $\mathbf{1 . 8}$ & $\mathbf{2 . 8}$ & $\mathbf{2 . 8}$ & $\mathbf{3 . 8}$ & $\mathbf{3 . 8}$ & $\mathbf{2 . 0}$ & $\mathbf{2 . 0}$ & $\mathbf{2 . 0}$ \\
\hline
\end{tabular}

Table 2. Nano-EHS investments reported to the NNI

\begin{tabular}{|l|l|l|l|l|l|l|l|}
\hline \multicolumn{7}{|c|}{ Investments by Fiscal Year, \$ M } \\
\hline $\mathbf{2 0 0 9}$ & $\mathbf{2 0 1 0}$ & $\mathbf{2 0 1 1}$ & $\mathbf{2 0 1 2}$ & $\mathbf{2 0 1 3}$ & $\mathbf{2 0 1 4}$ & $\mathbf{2 0 1 5}$ & $\mathbf{2 0 1 6}$ \\
\hline 3.5 & 3.4 & 3.2 & 7.2 & 6.2 & 5.1 & 6.7 & 5.9 \\
\hline
\end{tabular}


Annually, each Federal agency participating in the NNI is required to report its investments by topic, known as Principal Component Areas (PCAs). These investments are included in the annual NNI Supplement to the President's Budget; the figures that NIST reported for the EHS PCA for years 2009-2016 [13-20] are shown in Table 2. The funding levels in Table 2 were obtained by directly querying the NIST Operating Units and include both designated and division funds.

\subsection{Nano-EHS Program Researchers}

Since its inception in 2009, the nano-EHS Program has involved researchers from at least seven Divisions and three Laboratories (Operating Units) within NIST. From 2012-2016, the participating Labs and Divisions were:

Engineering Laboratory
Materials and Structural Systems Division, 731
Material Measurement Laboratory
Materials Science and Engineering Division, 642
Materials Measurement Science Division, 643
Biosystems and Biomaterials Division, 644
Chemical Sciences Division, 646
Applied Chemicals and Materials Division, 647
Physical Measurement Laboratory
Engineering Physics Division, 682

More than 90 researchers have worked on the Program over its eight-year span. The researchers, listed in Appendix A, are grouped into five categories: (1) NIST principal investigators; (2) NIST contributing staff members; (3) NRC postdoctoral fellows; (4) Postdoctoral research associates; and (5) Student research associates.

\section{NIST Nano-EHS Program Goals and Projects}

Throughout the tenure of the Program, the overarching focus has been on the development of measurement tools, defined here as methods, instrumentation, protocols and assays, and RMs. In developing measurement tools, studies on specific ENMs produced validated data that were published. The term "validated" implies that the data were reproducible and generated by metrologically valid methods to ensure the greatest accuracy and "quality" of the data.

From the outset, the Program focused on ENMs of greatest regulatory concern based on production volume, widespread use in NEPs, and likely hazards - namely, silver (Ag) and titanium dioxide $\left(\mathrm{TiO}_{2}\right)$ nanoparticles, and carbon nanotubes (CNTs), both singlewall (SW) and multi-wall (MW). Gold ( $\mathrm{Au}$ ) nanoparticles are a key benchmark material for physico-chemical and toxicological measurements and are important in advanced biomedical applications such as cancer treatment. As the Program progressed, the media in which measurements were performed transitioned from simple media (e.g., air, vacuum, water) to complex media, including both environmental (e.g., sediment, soil) and biological (e.g., blood, tissue) media. From 2012-2016, a portion of the Program was devoted to the application of measurement tools to specific ENM-NEP systems. Throughout the Program, many researchers led or contributed to the development of documentary standards and guidance documents in three standards-related organizations, 
namely ASTM International, the Organization for Economic Cooperation and Development (OECD), and the Organization for International Standardization (ISO).

\subsection{9-2011}

In 2009, a Steering Committee was formed whose function was to distribute the NanoEHS Initiative and NIST Director's funds. In 2009 and 2010, the funds were used to support single principal investigator research activities on the order of $\$ 25 \mathrm{~K}-\$ 150 \mathrm{~K}$. These activities focused on the development of methods to measure physico-chemical and biological properties of ENMs and on the development of ENM RMs. Examples of activities included the development of single-wall carbon nanotube and titanium dioxide RMs, methods for stabilizing silver nanoparticles in environmental and biological media, and protocols for assessing DNA damage in plants and organisms due to the presence of ENMs. These activities were not centrally coordinated, though some involved informal interactions between researchers at NIST and researchers from other government agencies, industry, and academia.

In 2011, the Steering Committee defined three Program focus areas: (1) the determination of surface attributes and transformations involving molecular adsorbents on ENM surfaces; (2) measurement of the concentrations of nano-silver and silver ions in various media; and (3) toxicological measurements. Although the activities within the focus areas were not centrally coordinated, the collaborations among NIST staff members increased substantially and channels for information sharing became well established.

\subsection{2-2014}

Beginning with the award of the Nanomanufacturing Initiative in 2012, a Technical Program Director was appointed to coordinate the Nano-EHS Program and the Steering Committee was disbanded. Three-year (2102-2014) Program and Spend Plans were developed by this Director and approved by the NIST Director's Office. The Plans were closely aligned with the research needs in the Nanomaterial Measurement Infrastructure (NMI) research category of the 2011 Nano-EHS Research Strategy [1]. Coordination with other NNI-NEHI agencies was strengthened and collaborations among various agencies were initiated and expanded, some continuing through 2016. Funds were allocated for specified research activities by designated researchers in the Divisions. The goals of the Program were two-fold:

(1) Enable other organizations to perform accurate and reproducible measurements by providing validated measurement tools

(2) Enable other organizations to detect and quantitatively characterize ENMs in NEPs using broadly available, commercial instruments

Specific deliverables by year for 2012-2014 are presented in the Program Plan document in Appendix B.

\subsubsection{Goal 1}

There is an endless combination of ENMs subjected to various media during their lifecycles; thus, it was clear that NIST could not determine the properties of all ENMs of interest to multiple stakeholder groups under all possible scenarios. To maximize the impact of its investment, NIST focused on the provision of measurement tools to enable 
other organizations to perform reproducible and accurate measurements on their own materials. This necessitated that the Program focus, to the extent possible, on common, affordable, and widely used instruments for which access was readily available to many organizations.

The objectives of Goal 1 were to conduct the following activities of high-priority as determined by interactions with NNI-NEHI agency and industrial representatives:

a) Develop and release RMs

b) Develop and broadly disseminate validated measurement methods and protocols

c) Lead and provide strong technical contributions to documentary and predocumentary standards development activities

\subsubsection{Goal 2}

For the duration of the Program, the number of NEPs on the market has continually increased [21]. Two prevalent NEPs are fabrics (textiles) containing nano-scale Ag, and NEPs manufactured from MWCNT-polymer composites. These two NEPs are the focus of the two objectives for Goal 2:

a) Develop methods to detect and quantitatively characterize key properties ${ }^{3}$ of Ag nanoparticles in fabrics

b) Develop methods to detect and quantitatively characterize key properties ${ }^{4}$ of MWCNTs in polymer matrix-based NEPs

Teams were established among NIST Program participants to address the objectives for Goals 1 and 2. Team members also worked closely with other key agency partners, notably two of the five US regulatory agencies, i.e., the Consumer Product Safety Commission (CPSC) and the FDA, as well as other National Metrology Institutes (NMIs), including NRC Canada and BAM in Germany, and the European Commission Institute for Reference Materials and Methods (now the Joint Research Centre).

\subsection{5-2016}

In 2015, four new project areas were defined by the Program Director in collaboration with several principal investigators in the Program. Funds were distributed to the seven participating Divisions for specific activities in these new projects and in an overarching measurement tool project that is a continuation of the work in Goal 1 above. These projects continued through 2016, when the NIST Nano-EHS Program formally ended.

The five project areas were:

1) Measurement Tools

2) Release of MWCNTs from Polymer Composites

3) Graphene in Microelectronic Devices

4) Engineered Nanomaterials in Heterogeneous Matrices

5) Lifecycle Speciation of Nano-silver

\footnotetext{
${ }^{3}$ For example, number concentration and size and size distribution of Ag NPs; distribution and chemical form of Ag in fabrics.

${ }^{4}$ For example, size and size distribution, morphology, and number concentration of MWCNTs; distribution of MWCNTs in matrix.
} 
Plans for each project were developed that included a team leader, team members, project goal, objectives, and deliverables by objective.

\section{NIST Nano-EHS Program Outputs}

During its eight-year tenure, the NIST Nano-EHS Program was prolific by any objective measure, producing a substantial number of publications, protocols, and RMs. Each output type will be described separately below.

\subsection{Publications}

The publications associated with the Program, presented in Appendix C, are organized by type and year published (2009-2018). The type and total number of each are as follows:

1) Archival journal publications: 212

2) Conference proceedings: 25

3) NIST Technical Notes: 3

4) Book chapters: 14

In addition, two team members are co-editors of the book Metrology and Standardization of Nanomaterials - Protocols and Industrial Innovations, which has 31 chapters.

One commonly used metric of a publication's impact is the Journal Impact Factor (JIF). JIF is a measure that reflects the yearly average number of citations to recent articles published in

Table 3. Number of publications per JIF range.

\begin{tabular}{|c|c|}
\hline JIF range & $\begin{array}{c}\text { Number of } \\
\text { publications }\end{array}$ \\
\hline $3-5$ & 46 \\
\hline $5-10$ & 63 \\
\hline $10-15$ & 17 \\
\hline
\end{tabular}
that journal. 126 of the 212 archival journal publications had JIF values greater than 3 . Table 3 shows the number of publications for several ranges of JIF values. JIF values of 5 or above are generally considered representative of "high impact" journals.

The journals with the greatest number of publications are:

- Analytical and Bioanalytical Chemistry: 23

- Environmental Science and Technology: 21

- Journal of Nanoparticle Research:13

- ACS Nano: 11

- Nanotoxicology: 9

These journals demonstrate the breadth of the NIST Nano-EHS Program, encompassing physico-chemical, environmental, and toxicological measurement research. As noted in Appendix C, several articles received special recognition from the journals in which they were published.

\subsection{Protocols and Assays}

Protocols and assays, defined here as step-by-step, reproducible, and validated procedures (methods), are an essential first step in the harmonization of ENM/NEP property measurements by enabling direct comparisons of data between laboratories and greater consistency in reporting data. Protocols may address, either separately or 
conjointly, sample preparation, conduct of measurements, and data analysis. The need for and importance of protocols are called out in the 2011 Nano-EHS Research Strategy [1], by agencies that regulate ENMs and NEPs, and by industry. Protocols can form the basis for the development of documentary standards published by ISO, ASTM International, and other standards-related organizations.

The list of nanomaterial measurement protocols and assays relevant to nano-EHS that NIST published from 2012-2018 is presented in Appendix D. NIST has a dedicated web site containing 24 publicly available nanomaterial measurement protocols; see https://www.nist.gov/mml/nano-measurement-protocols. These protocols have been published in the 1200 series of NIST Special Publications (SPs) with citable DOI names to provide persistent identification. Five of these protocols were developed in conjunction with the Center for the Environmental Implications of NanoTechnology, a multiuniversity entity led by Duke University with funding from the National Science Foundation and the Environmental Protection Agency. In addition, NIST team members have led the development of 11 assays that are publicly available on NCL's Assay Cascade Protocol web site https://ncl.cancer.gov/resources/assay-cascade-protocols.

\subsection{Reference Materials}

Reference materials (RMs) is a generic term used here to include NIST Reference Materials, NIST Traceable Reference Materials ${ }^{\mathrm{TM}}$ and NIST Standard Reference Materials $^{\mathrm{TM}}$ [22]. Definitions of these three types of RMs are provided on the NIST web site [23].

The RMs of relevance to the Nano-EHS Program are listed in Appendix E, which includes technical and sales information. As mentioned previously, the NIST Nano-EHS Program focused on ENMs of greatest regulatory concern based on production volume, widespread use in NEPs, and potential hazards - namely, silver (Ag) and titanium dioxide $\left(\mathrm{TiO}_{2}\right)$ nanoparticles and carbon nanotubes (CNTs), both single-wall (SW) and multi-wall (MW). From 2011-2018, NIST produced RMs for each of these ENMs. The three gold nanoparticle RMs, though released in 2008, are included in Appendix E because the large majority of the sales of these RMs occurred post-2008. To date, more than 2050 units of the nine RMs listed in Appendix E have been delivered to stakeholders world-wide.

\subsection{Documentary Standards}

ISO Technical Committee (TC) 229 on Nanotechnologies and ASTM International Committee E56 on Nanotechnology are arguably the two prevalent standards development organizations (SDOs) in nanotechnology. NIST researchers have played prominent leadership roles in these SDOs, both at the committee level and for specific technical standards.

Committee-level leadership positions include:

- Chair, US Technical Advisory Group (TAG) to ISO TC229 (2005-2010 and 2015-2016)

- Chair, US TAG to ISO TC229 Joint Working Group 2 (JWG2). Measurement and Characterization (2005-2016)

- Convener, ISO TC229 WG 3, Health, Safety and the Environment (2006-2013) 
- Chair, ASTM Committee E56 (2009-2015)

- Vice-Chair, ASTM Committee E56 (2015-2016)

- Co-Chair, ASTM Subcommittee E56.02, Physical and Chemical Characterization (2015-2016)

- Chair, ASTM Subcommittee E56.05, Liaison and International Cooperation (2012-2016)

- Chair, ASTM Subcommittee E56.07, Education and Workforce Development (2014-2016)

NIST researchers have also led or co-led the writing nearly 20 ISO and ASTM standards, including those currently under development. NIST researchers have also participated substantially in the development of other standards as approved experts serving on the US delegation to ISO 229 and as subject matter experts within ASTM E56. Another international effort in which NIST researchers have been involved is the Organization for Economic Co-operation and Development (OECD), which has produced guidelines pertinent to nano-EHS.

\section{NIST Nano-EHS Program Impacts}

The number, quality, and breadth of outputs are indicative of the significant impacts of the NIST Nano-EHS Program. Two case studies presented below illustrate the magnitude of specific impacts.

\subsection{Case Study I: Gold Nanoparticle Reference Materials}

In 2008, NIST released a series of three gold nanoparticle RMs: 8011, nominal diameter $=10 \mathrm{~nm}$; 8012, nominal diameter $=30 \mathrm{~nm}$; and 8013, nominal diameter $=60 \mathrm{~nm}$ (Fig. 2). Nanoparticle sizes were determined by six independent techniques, five of which use commonly available commercial instruments. While the RMs were originally intended to support pre-clinical biomedical efforts, they have found great utility in nano-EHS research and metrology development. Though anticipated to be used primarily to evaluate and qualify methodology and instrument performance for dimensional measurements, the RMs have been employed to develop and evaluate in vitro assays designed to assess biological response (e.g., cytotoxicity and

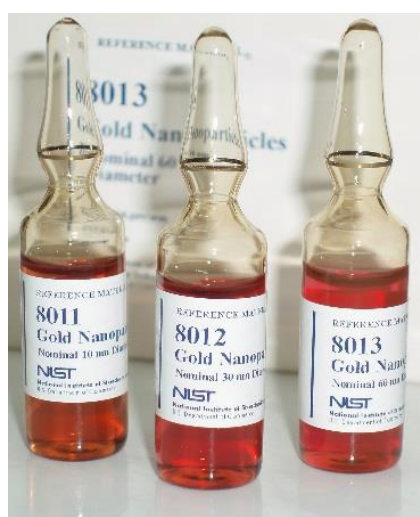

Fig. 2. Units of RMs 8011, 8012, and 8013. hemolysis) of ENMs. Further, the RMs have been used in interlaboratory test comparisons for the development or uncertainty analysis of three ASTM E56 and one ISO TC 229 standard. RMs 8012 and 8013 have been widely adopted as calibration standards for single particle inductively coupled plasma mass spectrometry, an important and rapidly emerging measurement technology. Collectively and as of April 2018, 1783 units of the gold RMs have been sold in nearly equal numbers to US and foreign organizations. 
A detailed impact study was performed on RM 8012 [11], with information collected and analyzed as of July 10, 2015. Sales statistics for RM 8012 are presented in Table 4. It is notable that, of the 479 units sold, nearly $90 \%$ were purchased by industry and government agencies, including National Metrology Institutes world-wide.

As of August 2016, there were more than 90 peer-reviewed publications and 8 non-peer reviewed documents (application notes, documentary standards, white papers, and notes) that utilize one or more of the three gold RMs (8011, 8012, and 8013) for a variety of purposes, or in which the gold RMs are a significant focus of discussion. A graph of the publications related to the gold RMs as of September 2015 is shown in Fig. 3. The principal uses of the gold RMs, from both published and anecdotal sources, include:

- Quality control and quality assurance (especially in analytical services labs and pharmaceutical companies)

- Method and instrument calibration

- Interlaboratory studies and comparisons

- Basic research

- Metrology research

- Method and technique comparisons

Table 4. Purchasers of RM 8012 as of September 2015

\begin{tabular}{|l|c|}
\hline Purchasers of RM 8012 & $\begin{array}{l}\text { Units, number or } \\
\text { \% of total sold }\end{array}$ \\
\hline Total number & 479 \\
\hline Domestic organizations & $47 \%$ \\
\hline Foreign organizations & $53 \%$ \\
\hline Industry & $46 \%$ \\
\hline Government & $42 \%$ \\
\hline Academia & $12 \%$ \\
\hline NMIs (part of government) & 12 \\
\hline
\end{tabular}

- Toxicological and environmental investigations

In summary, the NIST gold nanoparticle RMs have been used across the world, with significant impacts on nano-EHS, biomedical applications and nanometrology as demonstrated by sales and documented uses.

\subsection{Case Study II: Measurement Assurance for a Nanotoxicity Assay}

Cell-based toxicity assays (i.e., cytotoxicity assays) are commonly employed as screening tools to identify potential hazards associated with new chemicals and materials used in manufacturing. These assays are also used to evaluate biological effects associated with ENMs. Significant variability in such assays due to various sources have led to conflicting hazard data. For ENMs, some sources may include nanometer dimensions, large surface-to-volume ratios, wide ranges of composition and coatings, and the introduction of ENMs into living cell culture systems. The need to improve cell-based assays for nano-cytotoxicity has been demonstrated in interlaboratory studies coordinated by the International Alliance for Nano-EHS Harmonization wherein large variabilities in measurements were obtained. 
In response to this need, researchers in the Cell Systems Science group developed an approach to determine sources of variability that uses a novel measurement system to assess quality metrics for nano-cytotoxicity assay performance. The system is a 96-well plate based on the well-known MTS assay and uses protocols for cell line identification testing, dosing preparation, and pipetting procedures. Seven in-line quality assessment controls include reagent quality, cell seeding quality, cell function, and nanoparticle interference (Fig. 4). Measurements using the well plate and associated protocols yield a nano-cytotoxicity value and six additional results that characterize the measurement system. The system enables intermediate measurements pertinent to the assay that could be used to validate comparability of measurements between different laboratories and different nanomaterials.

The validity of the measurement system was assessed by an interlaboratory study including EMPA (Switzerland), NanoTEC (Thailand), Joint Research Centre (European Commission) and KRISS (Korea). The results of this study indicated several sources of variability associated with: (1) cell line identification; (2) rinsing attached cell layers; and (3) nanoparticle dispersion techniques. The large number of data sets from the different laboratories resulted in performance specifications for each of the in-line process controls and provided criteria that can be used to ensure comparability between data sets.

This work culminated in three publications [24-26] and the development of an ISO International standard (ISO/DIS 19007: Nanotechnologies - In vitro MTS assay for measuring the cytotoxic effect of nanoparticles) using the MTS assay in nanocytotoxicity testing [14-16]. This work serves as an exemplar for developing highquality assays and translating measurement science into a documentary standard.

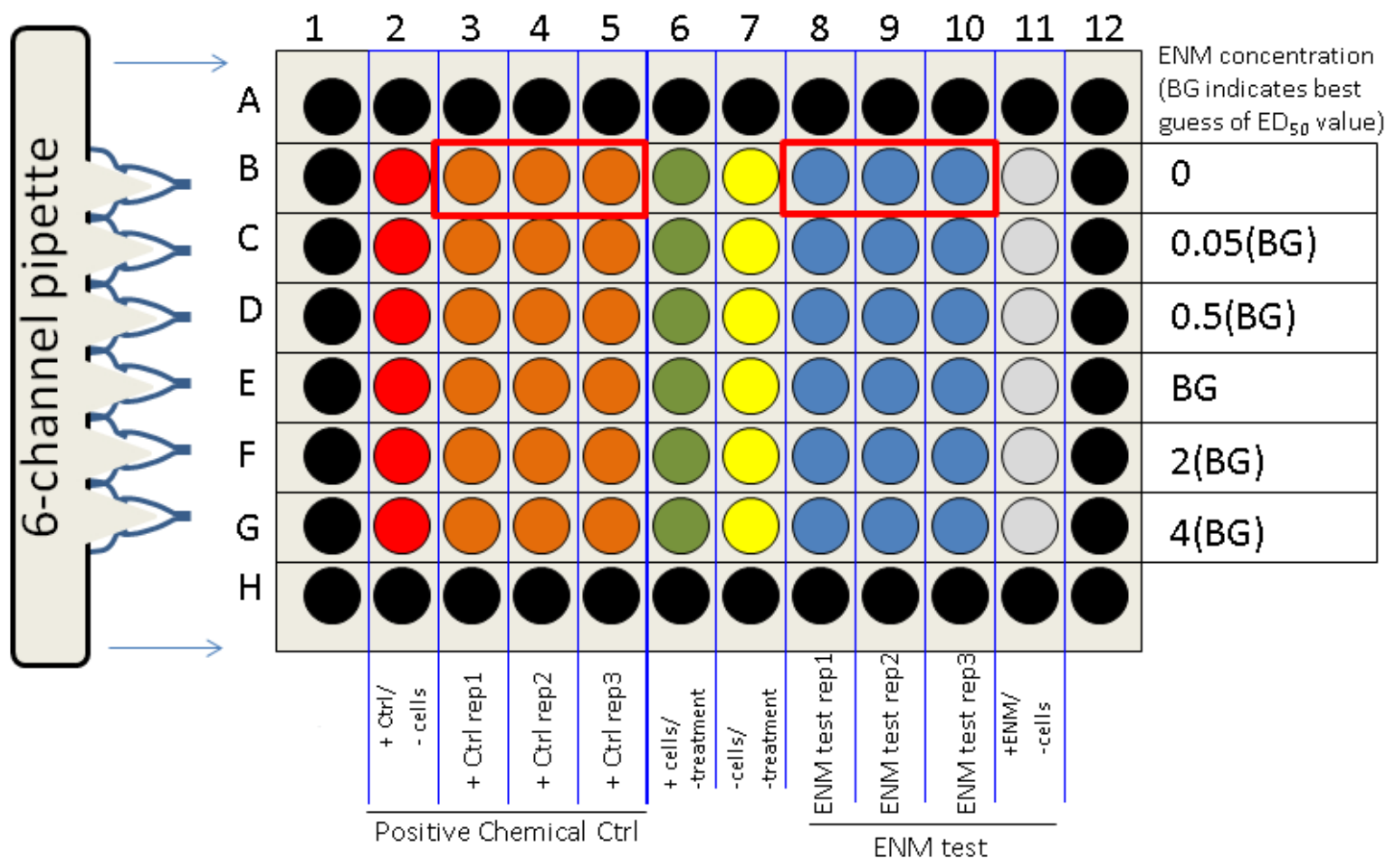

Fig. 4. 96-well plate layout for cytotoxicity assays on ENMs 


\section{Conclusions}

The eight-year NIST Nano-EHS Program has been successful by several objective measures. Outputs from the Program - publications, protocols, and RMs - are diverse and large in number. The significant impact of the Program has been demonstrated here through two case studies: the NIST gold nanoparticle RMs and the toxicity assay measurement assurance. Beginning in 2012, the teamwork demonstrated by all the researchers has been profound. The measurement infrastructure and knowledge base established through the NIST Nano-EHS Program will be beneficial in other innovative application areas of importance to commerce and healthcare, such as biomedical devices, energy generation, and water purification. The combined experience, expertise, and facilities resulting principally from the Program represent new core competencies at NIST, which can be further exploited to address a wide range of nanotechnology measurement issues of importance to a broad range of stakeholders, including industry and regulatory bodies. Finally, the interdivisional and interdisciplinary network of scientists, established in large part due to the Program, will have a lasting legacy that reaches beyond nano-EHS and nanotechnology. 


\section{Acknowledgements}

The authors would like to thank John Elliott and Elijah Petersen of NIST for contributing Case Study II: Measurement Assurance for a Nanotoxicity Assay.

\section{References}

[1] Executive Office of the President (2009) A Framework for Revitalizing American Manufacturing [accessed 2018 September 19] https://www.novoco.com/sites/default/files/atoms/files/wh_framework_121609_0.pdf

[2] Nanotechnology Timeline. [accessed 2018 September 19] http://www.nano.gov/timeline

[3] S. $189\left(108^{\text {th }}\right): 21$ st Century Nanotechnology Research and Development Act (2003) [accessed 2018 September 19] https://www.govtrack.us/congress/bills/108/s189

[4] National Science and Technology Council (2004) National Nanotechnology Initiative Strategic Plan (National Nanotechnology Initiative, Arlington VA), 48 pp. [accessed 2018 September 19] https://www.nano.gov/sites/default/files/pub_resource/nni_strategic_plan_2004.pdf

[5] National Science and Technology Council (2006) Environment, Health, and Safety Research Needs for Engineered Nanoscale Materials (National Nanotechnology Initiative, Arlington VA), 80 pp. [accessed 2018 September 19] https://www.nano.gov/sites/default/files/pub_resource/nni_ehs_research_needs.pdf

[6] National Science and Technology Council (2008) National Nanotechnology Initiative Strategy for Nanotechnology-Related Environmental, Health, and Safety Research (National Nanotechnology Initiative, Arlington VA), 102 pp. [accessed 2018 September 19] https://www.nano.gov/sites/default/files/pub_resource/nni_ehs_research_strategy.pdf

[7] National Science and Technology Council (2011) National Nanotechnology Initiative Environmental, Health, and Safety Research Strategy (National Nanotechnology Initiative, Arlington VA), 118 pp. [accessed 2018 September 19] https://www.nano.gov/sites/default/files/pub_resource/nni_2011_ehs_research_strategy.p $\underline{\mathrm{df}}$

[8] National Science and Technology Council (2014) Progress Review on the Coordinated Implementation of the National Nanotechnology Initiative 2011 Environmental, Health, and Safety Research Strategy (National Nanotechnology Initiative, Arlington VA), 52 pp. [accessed 2018 September 19] https://www.nano.gov/sites/default/files/pub_resource/2014_nni_ehs_progress_review.pd $\underline{\mathrm{f}}$

[9] Nanotechnology Characterization Laboratory, [accessed 2018 September 19] https://nanolab.cancer.gov/about-ncl/mission-objectives

[10] NIST Office of Standard Reference Materials (2008) NIST Reference Material 8011 [accessed 2018 September 19] https://www-S.nist.gov/srmors/view detail.cfm?srm=8011 [11] NIST Office of Standard Reference Materials (2008) NIST Reference Material 8012 [accessed 2018 September 19] https://www-s.nist.gov/srmors/view_detail.cfm?srm=8012 
[12] NIST Office of Standard Reference Materials (2008) NIST Reference Material 8013 [accessed 2018 September 19] https://www-s.nist.gov/srmors/view_detail.cfm?srm=8013 [13] National Science and Technology Council (2010) The National Nanotechnology Initiative Supplement to the President's 2011 Budget (National Nanotechnology Initiative, Arlington VA), 72 pp. [accessed 2018 September 19] https://www.nano.gov/sites/default/files/pub_resource/nni_2011_budget_supplement.pdf

[14] National Science and Technology Council (2011) The National Nanotechnology Initiative Supplement to the President's 2012 Budget (National Nanotechnology Initiative, Arlington VA), 56 pp. [accessed 2018 September 19] https://www.nano.gov/sites/default/files/pub_resource/nni_2012_budget_supplement.pdf [15] National Science and Technology Council (2012) The National Nanotechnology Initiative Supplement to the President's 2013 Budget (National Nanotechnology Initiative, Arlington VA), 76 pp. [accessed 2018 September 19] https://www.nano.gov/sites/default/files/pub_resource/nni_2013_budget_supplement.pdf [16] National Science and Technology Council (2013) The National Nanotechnology Initiative Supplement to the President's 2014 Budget (National Nanotechnology Initiative, Arlington VA), 88 pp. [accessed 2018 September 19] https://www.nano.gov/sites/default/files/pub_resource/nni_fy14_budget_supplement.pdf [17] National Science and Technology Council (2014) The National Nanotechnology Initiative Supplement to the President's 2015 Budget (National Nanotechnology Initiative, Arlington VA), 86 pp. [accessed 2018 September 19] https://www.nano.gov/sites/default/files/pub_resource/nni_fy15_budget_supplement.pdf [18] National Science and Technology Council (2015) The National Nanotechnology Initiative Supplement to the President's 2016 Budget (National Nanotechnology Initiative, Arlington VA), 104 pp. [accessed 2018 September 19] https://www.nano.gov/sites/default/files/pub_resource/nni_fy16_budget_supplement.pdf

[19] National Science and Technology Council (2016) The National Nanotechnology Initiative Supplement to the President's 2017 Budget (National Nanotechnology Initiative, Arlington VA), 112 pp. [accessed 2018 September 19] https://www.nano.gov/sites/default/files/pub_resource/nni_fy17_budget_supplement.pdf

[20] National Science and Technology Council (2017) The National Nanotechnology Initiative Supplement to the President's 2018 Budget (National Nanotechnology Initiative, Arlington VA), 86 pp. [accessed 2018 September 19] https://www.nano.gov/sites/default/files/pub_resource/NNI-FY18-BudgetSupplement.pdf

[21] Vance ME, et al. (2015) Nanotechnology in the real world: Redeveloping the nanomaterials consumer products inventory. Beilstein Journal of Nanotechnology 6:1769-1780.

[22] About NIST SRMs (National Institute of Standards and Technology, Gaithersburg MD) [accessed 2018 September 19] https://www.nist.gov/srm/about-nist-srms

[23] SRM Definitions (National Institute of Standards and Technology, Gaithersburg MD) [accessed 2018 September 19] https://www.nist.gov/srm/srm-definitions 
[24] Rosslein M, et al. (2015) The use of cause-and-effect analysis to design a highquality nano-cytotoxicity assay. Chemical Research in Toxicology 28(1):21-30.

https://doi.org/10.1021/tx500327y

[25] Toman B, Rosslein M, Elliott J, Petersen EJ (2016) Estimation and uncertainty analysis of dose response in an inter-laboratory experiment. Metrologia 53(1):S40-S45. https://doi.org/10.1088/0026-1394/53/1/S40

[26] Elliott JT, et al. (2017) Toward achieving harmonization in a nano-cytotoxicity assay measurement through an interlaboratory comparison study. Altex 34(2):201-218. https://doi.org/10.14573/altex.1605021 


\title{
Appendix A: Nano-EHS Program Researchers
}

(most recent position held)

NIST Staff: Principal Investigators

John Elliott

Jeffrey Fagan

Jeffrey Gilman

Justin Gorham

Vincent Hackley

Angela Hight-Walker

R. David Holbrook

Robert MacCuspie*

Elisabeth Mansfield

Karen Murphy

Bryant Nelson

Elijah Petersen

John Pettibone

Vytas Reipa

Keana Scott

LiPiin Sung

Andras Vlàdàr

Michael Winchester
NIST Staff: Contributing Members

Donald Atha

T. J. Cho

Miral Dizdaroglu

Shannon Hanna*

Deborah Stanley Jacobs

Pawel Jaruga

Monique Johnson

Peter Krommenhoek*

Stephen Long

Rabia Oflaz

Alex Peterson

Savelas Rabb

Marc Salit

Blaza Toman

Wyatt Vreeland

Stephanie Watson

Jeremiah Woodcock

Lee $\mathrm{Yu}$

Rolf Zeisler

Justin Zook

\author{
NRC Postdoctoral Fellows \\ Mark Bailey \\ Michelle Blickley \\ Christopher Brown \\ Danielle Cleveland \\ Chelsea Davis \\ Sherrie Elzey \\ John Heddleston \\ Constantine Khripin \\ Stephanie Lam \\ Christian Long \\ Stacey Louie \\ Bryce Marquis \\ Grant Myers \\ Nathan Orloff \\ Fatima Sequeira \\ Christopher Sims
}

*the researcher is no longer at NIST 
NIST Associates: Post-docs

Jens Breffke

Bryan Calderon Jimenez

Ning Chen

Guangun Cheng

Hsiang Chun Hsueh

Hind El Hadri

Julien Gigault

Preshagar Kavuri

Sung Kim

Thomas Lam

Jingyu Liu

Arnab Mukherjee

Antonio R. Montoro Bustos

Bharath Natarajan

Liz Nguyen

Tinh Nguyen

Yongyan Pang

Yanmei Piao

Vinayak Rastogi

Carlos Silvera Batista

Julian Taurozzi

Vipin Tondare

De-Hao Tsai

Ji Yeon Huh

Minhua Zhao

NIST Associates: Students

George Caceres

Yu-Lun Cheng

Yu-Fang Chuang

Anne Galyean

Carly Geronimo

James Ging

Sin-Ru Huang

Samuel Norris

Bastien Pellegrin

Cristina Rios Valdez

Brian Stock

Jiaojie Tan

Chun-Chieh Tien

Chen-Hsiang Tsai 


\section{Appendix B: Nano-EHS Initiative Program Plan, FY12-14}

Excerpts from the Program Plan are given below.

\section{Program Goals, Objectives, and Deliverables}

The technical work described below will significantly advance the establishment of a nanomaterial measurement infrastructure consisting of critical tools-standards, measurement methods, and validated data and models. The technical scope of the work will encompass four of the five Research Needs identified in the Nanomaterial Measurement Infrastructure Research Chapter of the NNI 2011 Nano-EHS Research Strategy: (1) determination of the physico-chemical properties of ENMs, a necessary first step in exposure and hazard evaluation; (2) detection of ENMs and NEPs; (3) evaluation of transformations of ENMs; and (4) evaluation of biological responses to ENMs and NEPs. The Program will provide the metrological foundation and measurement tools essential to the fifth Research Need, evaluation of release mechanisms of ENMs from NEPs. To maximize the relevance and impact of NIST work, FY12-FY14 priorities in Research Needs (1) and (2) are MWNCTs in polymer matrix-based NEPs such as sporting goods, and Ag NPs in NEPs such as fabrics. These ENM-NEP priorities are also consistent with those of the NanoRelease Project, a group of international representatives and technical experts from government agencies, industry, non-governmental organizations, and universities focused on the identification and development of methods to detect and characterize ENMs released from NEPs.

Goal 1: Enable other organizations to perform accurate, precise, and reproducible measurements by providing measurement tools

A. Objective: Develop and release standard reference materials (SRMs) and reference materials (RMs)

\begin{tabular}{|c|l|c|l|}
\hline \multicolumn{2}{|l|}{ Task } & FY & Deliverable \\
\hline i & $\begin{array}{l}\text { Develop methods for next- } \\
\text { generation SRMs and RMs, i.e., } \\
\text { zeta potential measurement, } \\
\text { positive toxicity controls }\end{array}$ & 12 & Progress reports \\
\hline ii & $\begin{array}{l}\text { Complete SRMs and RMs for key } \\
\text { ENMs (TiO) and Ag NPs and } \\
\text { single-wall CNTs) certified for } \\
\text { specific surface area and } \\
\text { dimensions }\end{array}$ & 12 & SRMs and RMs \\
\hline iii & $\begin{array}{l}\text { Demonstrate the applicability of } \\
\text { new hyphenated instruments to } \\
\text { next generation SRMs and RMs, } \\
\text { i.e., ENMs in complex matrices } \\
\text { and Ag NPs in aqueous media }\end{array}$ & $12-$ & Progress reports \\
\hline
\end{tabular}




\begin{tabular}{|c|l|c|l|}
\hline \multirow{5}{*}{ iv } & $\begin{array}{l}\text { Design and produce prototype } \\
\text { SRMs and RMs for zeta potential } \\
\text { measurement and positive } \\
\text { toxicity controls }\end{array}$ & $\begin{array}{c}12- \\
13\end{array}$ & $\begin{array}{l}\text { Progress reports, } \\
\text { prototype SRMs and } \\
\text { RMs }\end{array}$ \\
\hline vi & $\begin{array}{l}\text { Design and produce prototype } \\
\text { SRMs and RMs for determination } \\
\text { of chirality in purified SWCNTs }\end{array}$ & $\begin{array}{c}12- \\
13\end{array}$ & $\begin{array}{l}\text { Progress reports, } \\
\text { SRMs and RMs }\end{array}$ \\
\hline $\begin{array}{l}\text { Develop methods and produce } \\
\text { prototype SRMs and RMs for } \\
\text { ENMs in complex matrices such } \\
\text { as soil }\end{array}$ & $\begin{array}{c}13- \\
\text { vii }\end{array}$ & $\begin{array}{l}\text { Progress reports, } \\
\text { prototype SRMs and } \\
\text { prototype SRMs and RMs for } \\
\text { determination of concentration of } \\
\text { total Ag, Ag ions, and Ag NPs in } \\
\text { relevant media }\end{array}$ & $13-$ \\
\hline viii & $\begin{array}{l}\text { Evaluate potential for RMs on } \\
\text { other key ENMs, } i . e ., \text { MWCNTs, } \\
\text { CeO NPs, and nanoclays }\end{array}$ & $\begin{array}{l}\text { Progress reports, } \\
\text { prototype SRMs and } \\
\text { RMs }\end{array}$ \\
\hline ix & $\begin{array}{l}\text { Initiate production of SRMs and } \\
\text { RMs for zeta potential } \\
\text { measurement, positive toxicity } \\
\text { controls, and determination of } \\
\text { chirality in purified SWCNTs }\end{array}$ & 14 & Progress reports \\
\hline
\end{tabular}

B. Objective: Develop and broadly disseminate validated measurement protocols and assays

\begin{tabular}{|c|l|c|l|}
\hline \multicolumn{2}{|l|}{ Task } & FY & Deliverable \\
\hline i & $\begin{array}{l}\text { Prepare manuscripts on three } \\
\text { NIST protocols for dispersion of } \\
\text { TiO2 in various media }\end{array}$ & 12 & $\begin{array}{l}\text { NIST Special } \\
\text { Publications (SPs) } \\
\text { NIST website postings }\end{array}$ \\
\hline ii & $\begin{array}{l}\text { Demonstrate the adequacy and } \\
\text { extensibility of at least two } \\
\text { existing in vitro and in vivo } \\
\text { toxicity assays to ENMs }\end{array}$ & 12 & $\begin{array}{l}\text { Progress reports, } \\
\text { publications }\end{array}$ \\
\hline iii & $\begin{array}{l}\text { Complete a VAMAS } \\
\text { interlaboratory study (ILS) on } \\
\text { chirality measurements of single } \\
\text { wall CNT mixtures and develop } \\
\text { a protocol }\end{array}$ & $12-$ & $\begin{array}{l}\text { Report on ILS results } \\
\text { NIST SP on protocol } \\
\text { NIST website posting }\end{array}$ \\
\hline iv & $\begin{array}{l}\text { Develop protocols to stabilize } \\
\text { soluble NPs such as Ag }\end{array}$ & $12-$ & $\begin{array}{l}\text { NIST Special } \\
\text { Publication (SP) } \\
\text { NIST website posting }\end{array}$ \\
\hline
\end{tabular}




\begin{tabular}{|c|l|c|l|}
\hline $\mathrm{v}$ & $\begin{array}{l}\text { Develop in vitro and in vivo } \\
\text { toxicity assays, based on } \\
\text { existing or new assays }\end{array}$ & $\begin{array}{c}13- \\
14\end{array}$ & $\begin{array}{l}\text { Progress reports, } \\
\text { publications }\end{array}$ \\
\hline vi & $\begin{array}{l}\text { Evaluate and initiate } \\
\text { development of sample } \\
\text { preparation and measurement } \\
\text { protocols for other key ENMs, } \\
\text { i.e., MWCNTs, and CeO NPs, } \\
\text { and nanoclays }\end{array}$ & $\begin{array}{c}13- \\
\text { veports by study } \\
\text { groups (internal and } \\
\text { external) and on ILS's } \\
\text { initiated in VAMAS } \\
\text { and ASTM E56 }\end{array}$ \\
\hline $\begin{array}{l}\text { Develop draft protocols for the } \\
\text { use of hyphenated instruments, } \\
\text { e.g., DMA/AFFF/ICP-MS }\end{array}$ & 14 & Progress reports \\
\hline
\end{tabular}

C. Objective: Lead and provide strong technical contributions to documentary and pre-documentary standards development activities

\begin{tabular}{|c|c|c|c|}
\hline \multicolumn{2}{|c|}{ Task } & FY & Deliverable \\
\hline $\mathrm{i}$ & $\begin{array}{l}\text { Increase staff leadership and } \\
\text { participation in nano-EHS- } \\
\text { related SDOs and pre- } \\
\text { standardization organizations }\end{array}$ & $\begin{array}{l}12- \\
14\end{array}$ & $\begin{array}{l}\text { Listing of leadership } \\
\text { positions and active } \\
\text { staff members }\end{array}$ \\
\hline ii & $\begin{array}{l}\text { Lead and participate in the } \\
\text { completion and publication of } \\
\text { ongoing work items }\end{array}$ & $\begin{array}{l}12- \\
13\end{array}$ & $\begin{array}{l}\text { Listing of published } \\
\text { standards with noted } \\
\text { NIST leadership role }\end{array}$ \\
\hline iii & $\begin{array}{l}\text { Lead and participate in the } \\
\text { development of new work items }\end{array}$ & $\begin{array}{l}12- \\
14\end{array}$ & $\begin{array}{l}\text { Listing of new work } \\
\text { items with noted NIST } \\
\text { leadership role } \\
\text { Progress reports }\end{array}$ \\
\hline iv & $\begin{array}{l}\text { Co-organize workshops that } \\
\text { enable the prioritization and } \\
\text { increased use and value of } \\
\text { documentary standards }\end{array}$ & $\begin{array}{c}12- \\
14\end{array}$ & Workshop reports \\
\hline $\mathrm{v}$ & $\begin{array}{l}\text { Facilitate communication, } \\
\text { cooperation, and coordination of } \\
\text { activities among SDOs }\end{array}$ & $\begin{array}{l}12- \\
14\end{array}$ & $\begin{array}{l}\text { Reports describing } \\
\text { actions taken }\end{array}$ \\
\hline
\end{tabular}


Goal 2: Enable other organizations to detect and quantitatively characterize ENMs in NEPs using broadly available, commercial instruments

A. Objective: Develop methods to detect and quantitatively characterize Ag NPs in fabrics

\begin{tabular}{|c|c|c|c|}
\hline \multicolumn{2}{|c|}{ Task } & \multirow[b]{2}{*}{$\begin{array}{r}\mathbf{F Y} \\
12 \\
\end{array}$} & \multirow[b]{2}{*}{$\begin{array}{l}\text { Deliverable } \\
\\
\text { Progress reports, } \\
\text { publications }\end{array}$} \\
\hline $\mathrm{i}$ & $\begin{array}{l}\text { Evaluate the applicability, } \\
\text { advantages, and limitations of } \\
\text { FE-SEM, TEM, AFM, ICP-MS, } \\
\text { SEC, and XPS for the detection } \\
\text { of Ag NPs; develop sample } \\
\text { preparation approaches for each } \\
\text { method }\end{array}$ & & \\
\hline ii & $\begin{array}{l}\text { Evaluate the applicability, } \\
\text { advantages, and limitations of } \\
\text { FE-SEM, TEM, AFM, ICP-MS, } \\
\text { SEC, and XPS for quantitative } \\
\text { measurements of Ag NPs; } \\
\text { identify specific properties that } \\
\text { can be determined with each } \\
\text { method }\end{array}$ & $\begin{array}{c}12- \\
13\end{array}$ & $\begin{array}{l}\text { Progress reports, } \\
\text { publications }\end{array}$ \\
\hline iii & $\begin{array}{l}\text { Generate data and associated } \\
\text { measurement uncertainties using } \\
\text { FE-SEM, TEM, AFM, ICP-MS, } \\
\text { SEC, and XPS }\end{array}$ & $\begin{array}{c}13- \\
14\end{array}$ & $\begin{array}{l}\text { Progress reports, } \\
\text { publications }\end{array}$ \\
\hline iv & $\begin{array}{l}\text { Evaluate the feasibility of } \\
\text { extending the capabilities of FE- } \\
\text { SEM, TEM, AFM, ICP-MS, } \\
\text { SEC, and XPS, (e.g., high } \\
\text { throughput and three- } \\
\text { dimensional measurements) for } \\
\text { the detection and } \\
\text { characterization of Ag NPs }\end{array}$ & 14 & $\begin{array}{l}\text { Progress reports, } \\
\text { publications }\end{array}$ \\
\hline
\end{tabular}


B. Objective: Develop methods to detect and quantitatively characterize MWCNTs in polymer matrix-based NEPs

\begin{tabular}{|c|c|c|c|}
\hline \multicolumn{2}{|c|}{ Task } & FY & Deliverable \\
\hline $\mathrm{i}$ & $\begin{array}{l}\text { Evaluate the applicability, } \\
\text { advantages, and limitations of FE- } \\
\text { SEM, TEM, AFM, ICP-MS, SEC, } \\
\text { and XPS for the detection of } \\
\text { MWCNTs; develop sample } \\
\text { preparation approaches for each } \\
\text { method }\end{array}$ & 12 & $\begin{array}{l}\text { Progress reports, } \\
\text { publications }\end{array}$ \\
\hline ii & $\begin{array}{l}\text { Evaluate the applicability, } \\
\text { advantages, and limitations of FE- } \\
\text { SEM, TEM, AFM, ICP-MS, SEC, } \\
\text { and XPS for quantitative } \\
\text { measurements of MWCNTs; } \\
\text { identify specific properties that } \\
\text { can be determined with each } \\
\text { method }\end{array}$ & $\begin{array}{c}12- \\
13\end{array}$ & $\begin{array}{l}\text { Progress reports, } \\
\text { publications }\end{array}$ \\
\hline iii & $\begin{array}{l}\text { Generate data and associated } \\
\text { measurement uncertainties using } \\
\text { FE-SEM, TEM, AFM, ICP-MS, } \\
\text { SEC, and XPS }\end{array}$ & $\begin{array}{c}13- \\
14\end{array}$ & $\begin{array}{l}\text { Progress reports, } \\
\text { publications }\end{array}$ \\
\hline iv & $\begin{array}{l}\text { Evaluate the feasibility of } \\
\text { extending the capabilities of FE- } \\
\text { SEM, TEM, AFM, ICP-MS, SEC, } \\
\text { and XPS, (e.g., high throughput } \\
\text { and three-dimensional } \\
\text { measurements) for the detection } \\
\text { and characterization of MWCNTs }\end{array}$ & 14 & $\begin{array}{l}\text { Progress reports, } \\
\text { publications }\end{array}$ \\
\hline
\end{tabular}




\section{Appendix C: Nano-EHS Program Publications}

(in increasing chronological order by type of publication)

\section{Archival Journal Articles}

1. Hackley VA, Fritts M, Kelly JF, Patri AK, Rawle AF (August 2009) Enabling standards for nanomaterial characterization. InfoSim - Informative Bulletin of the Interamerican Metrology System, The Organization of American States, 24-29.

2. Duan J, Park K, MacCuspie R, Vaia RA, Pachter R (2009) Optical properties of rodlike metallic nanostructures: insight from theory and experiment. Journal of Physical Chemistry C 113:15524-15532. https://doi.org/10.1021/jp902448f

3. Decker JE, et al. (2009) Sample preparation protocols for realization of reproducible characterization of single-wall carbon nanotubes. Metrologia 46(6):682-692. https://doi.org/10.1088/0026-1394/46/6/011

4. Choi J, Wang NS, Reipa V (2009) Electrochemical reduction synthesis of photoluminescent silicon nanocrystals. Langmuir 25(12):7097-7102. https://doi.org/10.1021/la9001829

5. Choi J, et al. (2009) Comparison of cytotoxic and inflammatory responses of photoluminescent silicon nanoparticles with silicon micron-sized particles in RAW 264.7 macrophages. Journal of Applied Toxicology 29(1):52-60. https://doi.org/10.1002/jat.1382

6. Dobrovolskas D, Mickevicius J, Tamulaitis G, Reipa V (2009) Photoluminescence of Si nanocrystals under selective excitation. Journal of Physics and Chemistry of Solids 70(2):439-443. https://doi.org/10.1016/j.jpcs.2008.11.013

7. Zhou Z, et al. (2009) Water soluble DNA-wrapped single-walled carbon, nanotube/quantum dot complexes. Small 5(19):2149-2155. https://doi.org/10.1002/smll.200801932

8. Kang HG, et al. (2009) Multimodal, nanoscale, hyperspectral imaging demonstrated on heterostructures of quantum dots and DNA-wrapped single-wall carbon nanotubes. ACS Nano 3(11):3769-3775. https://doi.org/10.1021/nn901075j

9. Kang H, et al. (2009) Probing dynamic fluorescence properties of single and clustered quantum dots towards quantitative biomedical imaging of cells. WIREs Nanomedicine and Nanobiotechnology 2(1):48-58. https://doi.org/10.1002/wnan.62

10. Tyner KM, et al. (2009) Comparing methods for detecting and characterizing metal oxide nanoparticles in unmodified commercial sunscreens. Nanomedicine 4(2):145159. https://doi.org/10.2217/17435889.4.2.145

11. Pease III LF, et al. (2009) Length distributions of single wall carbon nanotubes in aqueous suspensions measured by electrospray-differential mobility analysis. Small 5(24):2894-2901. https://doi.org/10.1002/smll.200900928

12. Simpson JR, Fagan JA, Hobbie EK, Hight Walker AR (2009) The effect of dispersant on defects in length-separated single wall carbon nanotubes measured by 
Raman spectroscopy. Carbon 47: 3238-3241.

https://doi.org/10.1016/j.carbon.2009.07.037

13. Xiao Y, et al. (2009) Anti-HER2 IgY antibody-functionalized single-walled carbon nanotubes for detection and selective destruction of breast cancer cells. BMC Cancer 9:351-1-11. https://doi.org/10.1186/1471-2407-9-351

14. Cho TJ, Hackley VA (2010) Fractionation and characterization of gold nanoparticles in aqueous solution: asymmetric-flow field flow fractionation with MALS, DLS, and UV-Vis detection. Analytical and Bioanalytical Chemistry 398:2003-2018. https://doi.org/10.1007/s00216-010-4133-6

15. Wu C, et al. (2010) Effect of nanoparticle clustering on the effective thermal conductivity of concentrated silica colloids. Physical Review E 81:011406-1-7. https://doi.org/10.1103/PhysRevE.81.011406

16. Dair BJ, et al. (2010). The effect of substrate material on silver nanoparticle antimicrobial efficacy. Journal of Nanoscience and Nanotechnology 10:1-7. https://doi.org/10.1166/jnn.2010.3566

17. Cleveland D, et al. (2010) Chromatographic methods for the quantification of free and chelated gadolinium species in MRI contrast agent formulations. Analytical and Bioanalytical Chemistry 398(7-8):2987-2995. https://doi.org/10.1007/s00216-010$\underline{4226-2}$

18. Morrow JB, Arango C, Holbrook RD (2010) Association of quantum dot nanoparticles with Pseudomonas aeruginosa biofilm. Journal of Environmental Quality 39(6):1934-1941. https://doi.org/10.2134/jeq2009.0455

19. Holbrook RD, Kline CN, Filliben JJ (2010) Impact of source water quality on multiwall carbon nanotube coagulation. Environmental Science \& Technology 44(4):1386-1391. https://doi.org/10.1021/es902946j

20. Petersen EJ, Nelson BC (2010) Mechanisms and measurements of nanomaterialinduced oxidative damage to DNA. Analytical and Bioanalytical Chemistry 398:613-650. https://doi.org/10.1007/s00216-010-3881-7

21. Reipa V, Purdum G, Choi J (2010) Measurement of nanoparticle concentration using quartz crystal microgravimetry. Journal of Physical Chemistry B 49:1611216117. https://doi.org/10.1021/jp103861m

22. Huh JY, et al. (2010) Separation and characterization of double-wall carbon nanotube subpopulations. Journal of Physical Chemistry C 114:11343-11351. https://doi.org/10.1021/jp9110376

23. Mansfield E, Kar A, Hooker S (2010) Application of quartz crystal microbalances at elevated temperatures as an alternative to TGA. Analytical Chemistry 82(24):9977-9982. https://doi.org/10.1021/ac102030z

24. Mansfield E, Kar A, Hooker S (2010) Application of thermogravimetric analysis in quality control of single-walled carbon nanotubes. Analytical and Bioanalytical Chemistry 396(3):1071-1077. https://doi.org/10.1007/s00216-009-3319-2 
25. Zhao MH, et al. (2010) Subsurface characterization of carbon nanotubes in polymer composites via quantitative electric force microscopy. Nanotechnology 21(33):225702-1-9. https://doi.org/10.1088/0957-4484/21/33/339801

26. Park JJ, et al. (2010) SPR imaging study of DNA wrapped single wall carbon nanotube (ssDNA-SWCNT) adsorption on a model biological (collagen) substrate. Soft Matter 6:5581-5588. https://doi.org/10.1039/c0sm00368a

27. Pease III LF, et al. (2010) Structural analysis of soft multicomponent nanoparticle clusters. ACS Nano 4(11):6982-6988. https://doi.org/10.1021/nn102106f

28. Xiao Y, et al. (2010). Dynamics and mechanisms of quantum dot nanoparticle cellular uptake. Journal of Nanobiotechnology 8:13-1-9.

29. Sebby KB, Mansfield E (2010) The stability and surface coverage of polymer stabilized gold nanoparticles. eCells and Materials 20(S3):234.

30. MacCuspie RI, Allen AJ, Hackley VA (2011) Dispersion stabilization of silver nanoparticles in synthetic lung fluid studied under in situ conditions. Nanotoxicology 5(2):140-156. https://doi.org/10.3109/17435390.2010.504311

31. Taurozzi JS, Hackley VA, Wiesner MR (2011) Ultrasonic dispersion of nanoparticles for environmental, health and safety assessment - issues and recommendations. Nanotoxicology 5(4):711-729. https://doi.org/10.3109/17435390.2010.528846

32. Tsai D-H, et al. (2011) Quantitative determination of competitive molecular adsorption on gold nanoparticles using attenuated total reflectance fourier transform infrared spectroscopy. Langmuir 27:9302-9313. https://doi.org/10.1021/la2005425

33. Roebben $\mathrm{G}$, et al. (2011) Interlaboratory comparison of size and surface charge measurements on nanoparticles prior to biological impact assessment. Journal of Nanoparticle Research 13:2675-2687. https://doi.org/10.1007/s11051-011-0423-y

34. Tantra R, et al. (2011) Dispersion stability of nanoparticles in ecotoxicological investigations: The need for adequate measurement tools. Journal of Nanoparticle Research 13:3765-3780. https://doi.org/10.1007/s11051-011-0298-y

35. Chinnapongse SL, MacCuspie RI, Hackley VA (2011) Persistence of singly dispersed silver nanoparticles in natural freshwaters, synthetic seawater, and simulated estuarine waters. Science of the Total Environment 409:2443-2450. https://doi.org/10.1016/j.scitotenv.2011.03.020

36. Tsai D-H, et al. (2011) Hydrodynamic fractionation of finite size gold nanoparticle clusters. Journal of the American Chemical Society 133:8884-8887. https://doi.org/10.1021/ja203328j

37. Zook JM, Rastogi V, Keene AM, Fagan J, MacCuspie RI (2011) Measuring gold nanoparticle agglomerate size distribution and dependence of localized surface plasmon resonance absorbance on agglomerate size using analytical ultracentrifugation. ACS Nano 5(10):8070-8079. https://doi.org/10.1021/nn202645b

38. Zook JM, Long SE, Cleveland D, Geronimo CLA, MacCuspie RI (2011) Measuring silver nanoparticle dissolution in complex biological and environmental matrices 
using UV-Visible absorbance. Analytical and Bioanalytical Chemistry 401(6):19932002. https://doi.org/10.1007/s00216-011-5266-y

39. MacCuspie RI, et al. (2011) Challenges for physical characterization of silver nanoparticles under pristine and environmentally relevant conditions. Journal of Environmental Monitoring 13(5):1212-1226. https://doi.org/10.1039/c1em10024f "Invited article on special issue on Environmental Nanotechnology"; "Top 10 Most Downloaded Articles in May and June of 2011"

40. Akaighe N, et al. (2011) Humic acid-mediated silver nanoparticle formation under environmentally relevant conditions. Environmental Science \& Technology 45(9):3895-3901. https://doi.org/10.1021/es103946g

41. Geronimo CLA, MacCuspie RI (2011) Antibody-mediated self-limiting selfassembly for quantitative analysis of nanoparticle surfaces by atomic force microscopy. Microscopy and Microanalysis 17(2):206-214. https://doi.org/10.1017/S1431927610094559

42. Cho TJ, Zangmeister RA, MacCuspie RI, Patri AK, Hackley VA (2011) Newkome type dendron stabilized gold nanoparticles: Syntheses, reactivity, and stability. Chemistry of Materials 23(10): 2665-2676. https://doi.org/10.1021/cm200591h

43. Tsai D-H, et al. (2011) Adsorption and conformation of serum albumin protein on gold nanoparticles investigated using dimensional measurements and in situ spectroscopic methods. Langmuir 27(6):2464-2477. https://doi.org/10.1021/la104124d

44. MacCuspie RI (2011) Colloidal stability of silver nanoparticles under biologically relevant conditions. Journal of Nanoparticle Research 13(7):2893-2908. https://doi.org/10.1007/s11051-010-0178-X

45. Zook JM, MacCuspie RI, Locascio LE, Halter MD, Elliot JT (2011) Stable nanoparticle aggregates/agglomerates of different sizes and the effect of their size on hemolytic cytotoxicity. Nanotoxicology 5(4):517-530. https://doi.org/10.3109/17435390.2010.536615

46. Fagan JA, Lin NJ, Zeisler R, Walker ARH (2011) Effects of gamma irradiation for sterilization on aqueous dispersions of length sorted carbon nanotubes. Nano Research 4(4):393-404. https://doi.org/10.1007/s12274-011-0094-0

47. Zeisler R, et al. (2011) Elemental analysis of a single-wall carbon nanotube candidate reference material. Analytical and Bioanalytical Chemistry 399(1):509517. https://doi.org/10.1007/s00216-010-4275-6

48. Choi J, Reipa V, Hitchins VM, Goering PL, Malinauskas RA (2011) Physicochemical characterization and in vitro hemolysis evaluation of silver nanoparticles. Toxicology Science 123(1):133-143. https://doi.org/10.1093/toxsci/kfr149

49. Henry TB, Petersen EJ, Compton RN (2011) Aqueous fullerene aggregates $(\mathrm{nC}(60))$ generate minimal reactive oxygen species and are of low toxicity in fish: a revision of previous reports. Current Opinion in Biotechnology 22(4):533-537. https://doi.org/10.1016/j.copbio.2011.05.511 
50. Pakarinen K, Petersen EJ, Leppanen MT, Akkanen J, Kukkonen JVK (2011) Adverse effects of fullerenes (nC(60)) spiked to sediments on Lumbriculus variegatus (Oligochaeta). Environmental Pollution 159(12):3750-3756. https://doi.org/10.1016/j.envpol.2011.07.014

51. Petersen EJ, Pinto RA, Mai DJ, Landrum PF, Weber Jr WJ (2011) Influence of polyethyleneimine graftings of multi-walled carbon nanotubes on their accumulation and elimination by and toxicity to Daphnia magna. Environmental Science \& Technology 45(3):1133-1138. https://doi.org/10.1021/es1030239

52. Petersen EJ, et al. (2011) Effects of polyethyleneimine-mediated functionalization of multi-walled carbon nanotubes on earthworm bioaccumulation and sorption by soils. Environmental Science \& Technology 45(8):3718-3724. https://doi.org/10.1021/es103004r

53. Zhang L, Petersen EJ, Huang QG (2011) Phase distribution of 14C-labeled multiwalled carbon nanotubes in aqueous systems containing model solids: peat. Environmental Science \& Technology 45(4):1356-1362. https://doi.org/10.1021/es1026097

54. Lehman JH, Terrones M, Mansfield E, Hurst KE, Meunier V (2011) Evaluating the characteristics of multiwall carbon nanotubes. Carbon 49:2581-2602. https://doi.org/10.1016/j.carbon.2011.03.028

55. Zammaraano M, et al. (2011) Revealing the interface in polymer nanocomposites. ACS Nano 5(4):3391-3399. https://doi.org/10.1021/nn102951n

56. Wang DL, et al. (2011) Effect of pigment type on the UV degradation of TiO2pigmented coatings. Journal of Coatings Technology and Research 8(1):19-33. https://doi.org/10.1007/s11998-009-9216-y

57. Tseng I-H, Watson SS, Sung LP (2011) Characterizing the dynamic behavior of nano-TiO2 agglomerates in suspensions by photo correlation spectroscopy. Journal of Nanoparticle Research 13(5):2195-2204. https://doi.org/10.1007/s11051-0109977-3

58. Fagan JA, et al. (2011) Carbon nanotubes: measuring dispersion and length. Advanced Materials 23:338-348. https://doi.org/10.1002/adma.201001756

59. Fagan JA, et al. (2011) Separation of empty and water-filled single-wall carbon nanotubes, ACS Nano 5(5):3943-3953. https://doi.org/10.1021/nn200458t

60. Elzey S, et al. (2012) Quantification of ligand packing density on gold nanoparticles using ICP-OES. Analytical and Bioanalytical Chemistry 403:145-149. https://doi.org/10.1007/s00216-012-5830-0

61. Tsai D-H, et al. (2012) Quantifying dithiothreitol displacement of functional ligands from gold nanoparticles. Analytical and Bioanalytical Chemistry 404:3015-3023. https://doi.org/10.1007/s00216-012-6418-4

62. Chavez J, MacCuspie RI, Kelley-Loughnane N, Stone MO (2012) Colormetric detection with aptamer-gold nanoparticle conjugates: effect of aptamer length on 
response. Journal of Nanoparticle Research 14(10):1166.

https://doi.org/10.1007/s11051-012-1166-0

63. Gorham JM, MacCuspie RI, Klein KL, Fairbrother DH, Holbrook RD (2012) UVinduced photochemical transformations of citrate-capped silver nanoparticles. Journal of Nanoparticle Research 14(10):1139. https://doi.org/10.1007/s11051$\underline{012-1139-3}$

64. Tsai D-H, et al. (2012) Tumor necrosis factor interaction with gold nanoparticles. Nanoscale 4(10):3208-3217. https://doi.org/10.1039/c2nr30415e

65. Stan G, DelRio FW, MacCuspie RI, Cook RF (2012) Nucleation kinetics and mechanical property characterization of polyethylene glycol brushes on bare gold substrates. Journal of Physical Chemistry B 116(10):3138-3147. DOI: 10.1021/jp211256f https://doi.org/10.1021/jp211256f

66. Koerner H, MacCuspie RI, Park K, Vaia RA (2012) In-situ UV/Vis, SAXS and TEM study of single phase Au nanoparticle growth. Chemistry of Materials 24(6):981-995. https://doi.org/10.1021/cm202633v

67. Schaeublin NM, et al. (2012) Does shape matter? Bioeffects of gold nanomaterials in a human skin cell model. Langmuir 28(6):3248-3258. https://doi.org/10.1021/la204081m

68. Nguyen T, et al. (2012) Characterization of surface accumulation and release of nanosilica during irradiation of polymer nanocomposites by ultraviolet light. Journal of Nanoscience and Nanotechnology 12(8):6202-6215. https://doi.org/10.1166/jnn.2012.6442

69. Gorham JM, Nguyen T, Bernard C, Stanley D, Holbrook RD (2012) Photo-induced surface transformations of silica nanocomposites. Surface and Interface Analysis 44(13):1572-1581. https://doi.org/10.1002/sia.5075

70. Szakal C, et al. (2012) Preparation and measurement methods for studying nanoparticle aggregate surface chemistry. Journal of Environmental Monitoring 14:1914-1925. https://doi.org/10.1039/c2em30048f "Invited Article in 2012 Emerging Investigators Issue"

71. Zook JM, Halter MD, Cleveland D, Long SE (2012) Disentangling the effects of polymer coatings on silver nanoparticle agglomeration, dissolution, and toxicity to determine mechanisms of nanotoxicity. Journal of Nanoparticle Research 14(10):1165. https://doi.org/10.1007/s11051-012-1165-1

72. Cleveland D, et al. (2012) Pilot estuarine mesocosm study on the environmental fate of silver nanomaterials leached from consumer products. Science of the Total Environment 421: 267-272. https://doi.org/10.1016/j.scitotenv.2012.01.025

73. Atha DH, et al. (2012) Copper oxide nanoparticle mediated DNA damage in terrestrial plant models. Environmental Science \& Technology 46(3):1819-1827. https://doi.org/10.1021/es202660k

74. Zeisler R, Oflaz R, Paul RL, Fagan JA, (2012) Use of neutron activation analysis for the characterization of single-wall carbon nanotube materials. Journal of 
Radioanalytical and Nuclear Chemistry 291(2):561-567.

https://doi.org/10.1007/s10967-011-1290-9

75. Sturgeon RE, et al. (2012) Determination of moisture content of single-wall carbon nanotubes. Analytical and Bioanalytical Chemistry 402(1): 429-438.

https://doi.org/10.1007/s00216-011-5509-y

76. Diagne F, et al. (2012) Polyelectrolyte and silver nanoparticle modification of microfiltration membranes to mitigate organic and bacterial fouling. Environmental Science \& Technology 46(7):4025-4033. https://doi.org/10.1021/es203945v

77. Petersen EJ, et al. (2012). Potential release pathways, environmental fate, and ecological risks of carbon nanotubes. Environmental Science \& Technology 45(23):9837-9856. https://doi.org/10.1021/es201579y

78. Singh N, et al. (2012) The role of iron redox state in the genotoxicity of ultrafine superparamagnetic iron oxide nanoparticles. Biomaterials 33(1):163-170. https://doi.org/10.1016/j.biomaterials.2011.09.087

79. Petersen EJ, Henry TB (2012) Methodological considerations for testing the ecotoxicity of carbon nanotubes and fullerenes: Environmental Toxicology and Chemistry 31(1):60-72. https://doi.org/10.1002/etc.710

80. Zhang LW, et al. (2012) Interactions of C-14-labeled multi-walled carbon nanotubes with soil minerals in water. Environmental Pollution 166:75-81. https://doi.org/10.1016/j.envpol.2012.03.008

81. Prabhu VM, Reipa V (2012) In situ electrochemical small-angle neutron scattering (eSANS) for quantitative structure and redox properties of nanoparticles. Journal of Physical Chemistry Letters 3(5):646-650. https://doi.org/10.1021/jz300124t

82. Nguyen T, et al. (2012) Characterization of surface accumulation and release of nanosilica during irradiation of polymer nanocomposites with ultraviolet. Journal of Nanoscience and Nanotechnology 12:6205-6215. https://doi.org/10.1166/jnn.2012.6442

83. Gu X, et al. (2012) Critical role of particle/polymer interphase in long-term performance of nanofilled polymeric coatings. Journal of Coatings Technology Research 9:251-267. https://doi.org/10.1007/s11998-011-9326-1

84. Watson S, Tseng I-H, Marray T, Pellegrin B, Comte J (2012) Pigment and nanofiller photoreactivity database. Journal of Coatings Technology Research 9(4):443-451. https://doi.org/10.1007/s11998-012-9408-8

85. Greenlee LF, Torrey JD, Amaro RL, Shaw JM (2012) Kinetics of zero valent iron nanoparticle oxidation in oxygenated water. Environmental Science \& Technology 46:12913-12920. https://doi.org/10.1021/es303037k

86. Goldstein N, Greenlee LE (2012) Influence of synthesis parameters on iron nanoparticle size and zeta potential. Journal of Nanoparticle Research 14:760-775. https://doi.org/10.1007/s11051-012-0760-5 
87. Greenlee LF, Hooker SA (2012) Development of stabilized zero valent iron nanoparticles. Desalination and Water Treatment 37:114-121. https://doi.org/10.1080/19443994.2012.661262

88. Khripin CY, Tu X, Howarter J, Fagan J, Zheng M (2012) Concentration measurement of length-fractionated colloidal single-wall carbon nanotubes. Analytical Chemistry 8(20):8733-8739. https://doi.org/10.1021/ac302023n

89. Sturgeon RE, et al. (2012) Determination of moisture content of single-wall carbon nanotubes. Analytical and Bioanalytical Chemistry 402:429-438. https://doi.org/10.1007/s00216-011-5509-y

90. Bancos S, Tsai D-H, Hackley VA, Weaver JL, Tyner KM (2012) Evaluation of viability and proliferation profiles on macrophages treated with silica nanoparticles in vitro via plate-based, flow cytometry, and Coulter counter assays. International Scholarly Research Notices Nanotechnology, 2012:454072-1-11. https://doi.org/10.5402/2012/454072

91. Gigault JC, Cho TJ, MacCuspie RI, Hackley VA (2013) Gold nanorod separation and characterization by asymmetric-flow field flow fractionation with UV-Vis detection. Analytical and Bioanalytical Chemistry 405:1191-1202. https://doi.org/10.1007/s00216-012-6547-9

92. Taurozzi JS, Hackley VA, Wiesner MR (2013) A standardised approach for the dispersion of titanium dioxide nanoparticles in biological media. Nanotoxicology 7(4):389-401. https://doi.org/10.3109/17435390.2012.665506

93. Roberts JR, et al. (2013) Pulmonary and cardiovascular responses of rats to inhalation of silver nanoparticles. Journal of Toxicology and Environmental Health, Part A 76(11):651-668. https://doi.org/10.1080/15287394.2013.792024

94. Gigault JC, Hackley VA (2013) Differentiation and characterization of isotopically modified silver nanoparticles in aqueous media using asymmetric-flow field flow fractionation coupled to optical detection and mass spectrometry. Analytica Chimica Acta 763:57-66. https://doi.org/10.1016/j.aca.2012.11.060

95. MacCuspie RI, Allen AJ, Martin MN, Hackley VA (2013) Just add water: reproducible singly dispersed silver nanoparticle suspensions on-demand. Journal of Nanoparticle Research 15:1760-1771. https://doi.org/10.1007/s11051-013-1760$\underline{9}$

96. Lee SM, Tsai D-H, Hackley VA, Brechbielb MW, Cook RF (2013) Surfaceengineered nanomaterials as X-ray absorbing adjuvant agents for Auger-mediated chemo-radiation. Nanoscale 5:5252-5256. https://doi.org/10.1039/c3nr00333g

97. Tsai D-H, Cho TJ, Elzey SR, Gigault JC, Hackley VA (2013) Quantitative analysis of dendron-conjugated cisplatin-complexed gold nanoparticles using scanning particle mobility mass spectrometry. Nanoscale 5:5390-5395. https://doi.org/10.1039/c3nr00543g

98. Gigault JC, Hackley VA (2013) Observation of size-independent effects in nanoparticle retention behavior during asymmetric-flow field-flow fractionation. 
Analytical and Bioanalytical Chemistry 405:6251-6258.

https://doi.org/10.1007/s00216-013-7055-2

99. Pettibone JM, Gigault JC, Hackley VA (2013) Discriminating the states of matter in metallic nanoparticle transformations: what are we missing? ACS Nano 7(3):24912499. https://doi.org/10.1021/nn3058517

100. Hackley VA, Stefaniak SB (2013) "Real-world" precision, bias, and betweenlaboratory variation for surface area measurement of a titanium dioxide nanomaterial in powder form. Journal of Nanoparticle Research 15:1742-1749. https://doi.org/10.1007/s11051-013-1742-y

101. Nguyen TM, Gigault JC, Hackley VA (2013) PEGylated gold nanorod separation based on aspect ratio: characterization by asymmetric-flow field flow fractionation with UV-Vis detection. Analytical and Bioanalytical Chemistry 406(6):1651-1659. https://doi.org/10.1007/s00216-013-7318-y

102. Stefaniak AB, et al. (2013) Nanoscale reference materials for environmental, health and safety measurements: needs, gaps and opportunities. Nanotoxicology 7(8):1325-1337. https://doi.org/10.3109/17435390.2012.739664

103. Nagy A, et al. (2013) Functionalization-dependent induction of cellular survival pathways by CdSe quantum dots in primary human bronchial epithelial cells. ACS Nano 7(10):8397-8411. https://doi.org/10.1021/nn305532k

104. Hunt PR, et al. (2013) Nanosilver suppresses growth and induces oxidative damage to DNA in Caenorhabditis elegans. Journal of Applied Toxicology 33:1131-1142. https://doi.org/10.1002/jat.2872

105. Nelson BC, et al. (2013) NIST gold nanoparticle Reference Materials do not induce oxidative DNA damage. Nanotoxicology 7:21-29. https://doi.org/10.3109/17435390.2011.626537

106. Petersen EJ, Tu X, Dizdaroglu M, Zheng M, Nelson BC (2013) Protective roles of single-wall carbon nanotubes in ultrasonication-induced DNA damage. Small 9:205-208. https://doi.org/10.1002/smll.201201217

107. Wang H-W, et al. (2013) Structure and stability of SnO2 nanocrystals and surfacebound water species. Journal of the American Chemical Society 135:6885-6895. https://doi.org/10.1021/ja312030e

108. Khripin CY, Fagan JA, Zheng M (2013) Spontaneous partition of carbon nanotubes in polymer-modified aqueous phases. Journal of the American Chemical Society 135(18):6822-6825. https://doi.org/10.1021/ja402762e

109. Nontapot K, Rastogi V, Fagan JA, Reipa V (2013) Size and density measurement of core-shell Si nanoparticles by analytical ultracentrifugation. Nanotechnology 24(15):155701-1-10. https://doi.org/10.1088/0957-4484/24/15/155701

110. Khripin CY, et al. (2013) High-resolution length fractionation of surfactantdispersed carbon nanotubes. Analytical Chemistry 85(3):1382-1388. https://doi.org/10.1021/ac303349q 
111. Mansfield E, Kar A, Wang CM, Chiaramonti AN (2013) Statistical sampling of carbon nanotube populations by thermogravimetric analysis. Analytical and Bioanalytical Chemistry 405:8207-8213. https://doi.org/10.1007/s00216-013-7221$\underline{6}$

112. Liu D, et al. (2013) Gold nanoparticle-based activatable probe for sensing ultralow levels of prostate-specific antigen. ACS Nano 7(6):5568-5576. https://doi.org/10.1021/nn401837q

113. Fagan JA, et al. (2013) Analyzing surfactant structures on length and chirality resolved $(6,5)$ single-wall carbon nanotubes by analytical ultracentrifugation. ACS Nano 7(4):3373-3387. https://doi.org/10.1021/nn4002165

114. Elzey S, et al. (2013) Real-time discrimination and elemental analysis of gold nanoparticles using ES-DMA coupled to ICP-MS. Analytical and Bioanalytical Chemistry 405:2279-2288. https://doi.org.10.1007/s00216-012-6617-z "Paper of the Year in 2013" and "Paper in Forefront" chosen by editors.

115. Whelton AJ, Nguyen T (2013) Contaminant migration from polymeric pipes used in buried potable water distribution systems: A review. Environmental Science \& Technology 43(7):679-751. https://doi.org/10.1080/10643389.2011.627005

116. Zhang L, Petersen EJ, Habteselassie MY, Mao L, Huang Q (2013) Biodegradation of 14C-labeled multi-walled carbon nanotubes. Environmental Pollution 181:335339. https://doi.org/10.1016/j.envpol.2013.05.058

117. Pakarinen K, et al (2013) A screening study on the fate of fullerenes (nC60) and their toxic implications in natural freshwaters. Environmental Toxicology and Chemistry 32(6):1224-1232. https://doi.org/10.1002/etc.2175

118. O'Carroll DM, Liu X, Mattison NT, Petersen EJ (2013) Impact of size on carbon nanotube transport in natural porous media. Journal of Colloid and Interface Science 390(1):96-104. https://doi.org/10.1016/j.jcis.2012.09.034

119. Nelson BC, et al. (2013) Interactions of NIST gold nanoparticle Reference Materials with DNA in both acellular and cellular models. Nanotoxicology 7(1):2129. https://doi.org/10.3109/17435390.2011.626537

120. Cho TJ, et al. (2014) Highly stable positively charged dendron-encapsulated gold nanoparticles. Langmuir 30:3883-3893. https://doi.org/10.1021/la5002013

121. Petersen EJ, et al. (2014) Identification and avoidance of potential artifacts and misinterpretations in nanomaterial ecotoxicity measurements. Environmental Science \& Technology 48:4226-4246. https://doi.org/10.1021/es4052999 "Critical Review Paper"

122. Gigault J, Pettibone JM, Schmitt C, Hackley VA (2014) Rational strategy for characterization of nanoscale particles by asymmetric-flow field flow fractionation: A tutorial. Analytica Chimica Acta 809:9-24. https://doi.org/10.1016/j.aca.2013.11.021 
123. Martin MN, Allen AJ, MacCuspie RI, Hackley VA (2014) Dissolution, agglomerate, morphology, and stability limits of protein-coated silver nanoparticles. Langmuir 30:11442-11452. https://doi.org/10.1021/la502973z

124. Nguyen TM, Gigault J, Hackley VA (2014) PEGylated gold nanorod separation based on aspect ratio: characterization by asymmetric-flow field flow fractionation with UV-Vis detection. Analytical and Bioanalytical Chemistry 406:1651-1659. https://doi.org/10.1007/s00216-013-7318-y

"Invited Article in Special Issue on Asymmetric-Flow Field Flow Fractionation"

125. Tsai D-H, et al. (2014) Controlled formation and characterization of dithiothreitolconjugated gold nanoparticle clusters. Langmuir 30:3397-3405.

https://doi.org/10.1021/la500044y

126. Gigault J, Nguyen TM, Pettibone JM, Hackley VA (2014) Accurate determination of the size distribution for polydisperse, cationic metallic nanomaterials by asymmetric-flow field flow fractionation. Journal of Nanoparticle Research 16:2735-2744. https://doi.org/10.1007/s11051-014-2735-1

127. Faussa EK, MacCuspie RI, Oyanedel-Craverc V, Smith JA, Swami NS (2014) Disinfection action of electrostatic versus steric-stabilized silver nanoparticles on E. coli under different water chemistries. Colloids and Surfaces B: Biointerfaces 113:77-84. https://doi.org/10.1016/j.colsurfb.2013.08.027

128. Petersen EJ, et al. (2014) Methods to assess the impact of UV irradiation on the surface chemistry and structure of multiwall carbon nanotube epoxy nanocomposites. Carbon 69:194-205. https://doi.org/10.1016/j.carbon.2013.12.016

129. Gorham JM, et al. (2014) Storage wars: how citrate-capped silver nanoparticle suspensions are affected by not-so-trivial decisions. Journal of Nanoparticle Research 16:2339. https://doi.org/10.1007/s11051-014-2339-9

130. Szakal C, Ugelow MS, Gorham JM, Konicek AR, Holbrook RD (2014) Visualizing nanoparticle dissolution by imaging mass spectrometry. Analytical Chemistry 86:3517-3524. https://doi.org/10.1021/ac404153q

131. Liu J, Murphy KE, MacCuspie RI, Winchester MR (2014) Capabilities of single particle inductively coupled plasma mass spectrometry for the size measurement of nanoparticles: a case study on gold nanoparticles. Analytical Chemistry 86:3405-3414. https://doi.org/10.1021/ac403775a

132. Ging J (2014) Development of a conceptual framework for evaluation of nanomaterials release from nanocomposites: Environmental and toxicological implications. Science of the Total Environment 473-474:9-19. https://doi.org/10.1016/j.scitotenv.2013.11.135

133. Holbrook RD, Rykaczewski K, Staymates ME (2014) Dynamics of silver nanoparticle release from wound dressings revealed via in-situ nanoscale imaging. Journal of Materials Science-Materials in Medicine 25(11):2481-2489. https://doi.org/10.1007/s10856-014-5265-6 
134. Atha DH, et al. (2014) Copper oxide nanoparticle mediated DNA damage in terrestrial plant models. Environmental Science \& Technology 48(20):12473-12473. https://doi.org/10.1021/es5047793

135. Petersen EJ, et al. (2014) The DNA damaging potential of photoactivated P25 titanium dioxide nanoparticles. Chemical Research in Toxicology 27(10):18771884. https://doi.org/10.1021/tx500340v

136. Edgington A, et al. Microscopic investigation of single-wall carbon nanotube uptake by Daphnia magna. Nanotoxicology 8:2-10. https://doi.org/10.3109/17435390.2013.847504

137. Mansfield E, Oreskovic TL, Goldstein NS, Jeerage KM (2014) Three-dimensional hydrogel constructs for dosing cells with nanoparticles. Nanotoxicology 8(4):394403. https://doi.org/10.3109/17435390.2013.790998

138. Mansfield E, Poling CM, Blacklock JL, Tyner KM (2014) Quantitative determination of nanoparticle surface coatings using microscale thermogravimetric analysis. Analytical Chemistry 86(3):1478-1484. https://doi.org/10.1021/ac402888v

139. David L, Feldman A, Mansfield E, Lehman J, Singh G (2014) Evaluating thermal damage resistance of graphene/carbon nanotube hybrid composite coatings. Scientific Reports 4:4311. https://doi.org/10.1038/srep04311

140. Pang Y, Watson SS, Sung L (2014) Surface degradation process affected by heterogeneity in nano-titanium dioxide filled acrylic urethane coatings under accelerated UV exposure. Polymer 55(25):6594-6603. https://doi.org/10.1016/j.polymer.2014.10.030

141. Wohlleben W, et al. (2014) A pilot interlaboratory comparison of protocols that simulate aging of nanocomposites and detect released fragments. Environmental Chemistry 11(4):402-418. https://doi.org/10.1071/EN14072

142. Fagan JA (2014) Isolation of specific small diameter single-wall carbon nanotube species via aqueous two-phase extraction. Advanced Materials 18:2800-2804. https://doi.org/10.1002/adma.201304873

143. Weber KP, et al. (2014) Effect of gold nanoparticles and ciprofloxacin on microbial catabolism: A community-based approach. Environmental Toxicology and Chemistry 33(1):44-51. https://doi.org/10.1002/etc.2412

144. Tsai D-H, et al. (2015) Orthogonal analysis of functional gold nanoparticles for biomedical applications. Analytical and Bioanalytical Chemistry 407(28):8411-22. https://doi.org/10.1007/s00216-015-9011-9 "Paper in Forefront" chosen by editors and "Best Paper in 2015"

145. Nguyen TM, Liu J, Hackley VA (2015) Fractionation and characterization of high aspect ratio gold nanorods using asymmetric-flow field flow fractionation and single particle inductively coupled plasma mass spectrometry. Chromatography 2:422-435. https://doi.org/10.3390/chromatography2030422 
146. Cho TJ, et al. (2015) Unexpected changes in functionality and surface coverage for Au nanoparticle PEI conjugates: Implications for stability and efficacy in biological systems. Langmuir 31:7673-7683. https://doi.org/10.1021/acs.langmuir.5b01634

147. Sung L, et al. (2015) A quantitative study of nanoparticle release from nanocoatings exposed to UV radiation. Journal of Coatings Technology and Research 12(1):121135. https://doi.org/10.1007/s11998-014-9620-9

148. Goodwin Jr. DG, et al. (2015) Interactions of microorganisms with polymer nanocomposite surfaces containing oxidized carbon nanotubes. Environmental Science \& Technology 49(9):5484-5492. https://doi.org/10.1021/acs.est.5b00084

149. Hume SL, et al. (2015) Timescale of silver nanoparticle transformation in neural cell cultures impacts measured cell response. Journal of Nanoparticle Research 17(7):315. https://doi.org/10.1007/s11051-015-3111-5

150. Goodwin Jr DG, et al. (2015) Interactions of microorganisms with polymer nanocomposites containing different loadings of oxidized single and multi-walled carbon nanotubes. Environmental Science \& Technology 49(9):5484-5492. https://doi.org/10.1021/acs.est.5b00084

151. Davis CS, Grolman DL, Karim A, Gilman JW (2015) What do we still need to understand to commercialize cellulose nanomaterials? Green Materials 3(3):53-58. https://doi.org/10.1680/jgrma.15.00013

152. Galyean AA, et al. (2015) Using light scattering to evaluate the separation of polydisperse nanoparticles. Analytica Chimica Acta 886:207-213. https://doi.org/10.1016/j.aca.2015.06.027

153. Montoro Bustos AR, Petersen EJ, Possolo A, Winchester MR (2015) Post hoc interlaboratory comparison of single particle ICP-MS size measurements of NIST Gold Nanoparticle Reference Materials. Analytical Chemistry 87(17):8809-8817. https://doi.org/10.1021/acs.analchem.5b01741

154. Petersen EJ, et al. (2015) Adapting OECD aquatic toxicity tests for use with manufactured nanomaterials: Key issues and consensus recommendations. Environmental Science \& Technology 49(16):9532-9547. https://doi.org/10.1021/acs.est.5b00997

155. Feng Y, et al. (2015) Degradation of 14C-labeled graphene via Fenton Reaction: Reaction rates, characterization of reaction products, and potential ecological effects. Water Research 84:49-57. https://doi.org/10.1016/j.watres.2015.07.016

156. Godwin H, et al. (2015) A perspective on the use of nanomaterial categorization for risk assessment and regulatory decision-making. ACS Nano 9(4):3409-3417. https://doi.org/10.1021/acsnano.5b00941

157. Kah M, et al. Carbon nanotubes in the environment: new threats or wonder materials. Environmental Toxicology and Chemistry 34(5):954-958. https://doi.org/10.1002/etc.2898 
158. Rosslein M, et al. (2015) The use of cause-and-effect analysis to design a highquality nano-cytotoxicity assay. Chemical Research in Toxicology 28(1):21-30. https://doi.org/10.1021/tx500327y

159. Sebby KB, Mansfield E (2015) Determination of the surface density of polyethylene glycol on gold nanoparticles by use of microscale thermogravimetric analysis. Analytical and Bioanalytical Chemistry 407(10):2913-2922. https://doi.org/10.1007/s00216-015-8520-X

160. Mansfield E, Feldman A, Chiaramonti AN, Lehman J, Curtin AE (2015) Morphological and electrical characterization of MWCNT papers and pellets. Journal of Research of the National Institute of Standards and Technology 120:304-315. https://doi.org/10.6028/jres.120.019

161. Gorham JM, et al. (2015) Detecting carbon in carbon: exploiting differential charging to obtain information on the chemical identity and spatial location of carbon nanotube aggregates in composites by imaging X-ray photoelectron spectroscopy. Carbon 96:1208-1216. https://doi.org/10.1016/j.carbon.2015.10.073

162. Zhao M, et al. (2015) New insights into subsurface imaging of carbon nanotubes in polymer composites via scanning electron microscopy. Nanotechnology 26(8):085703-1-12. https://doi.org/10.1088/0957-4484/26/8/085703

163. Tan J, et al. (2016) Electrospray differential mobility hyphenated with single particle mass spectrometry for characterization of nanoparticles and their aggregates. Analytical Chemistry 88(17):8545-55. https://doi.org/10.1021/acs.analchem.6b01544

164. Nguyen TM, Pettibone JM, Gigault J, Hackley VA (2016) In situ monitoring, separation, and characterization of gold nanorod transformation during seedmediated synthesis. Analytical and Bioanalytical Chemistry 408:2195-2201. https://dx.doi.org/10.1007/s00216-016-9366-6 Selected for "Issue Cover" and "Most Attractive Cover for 2016"

165. Davis CS, et al. (2016) Cure temperature influences composite electrical properties by carbon nanotube-rich domain formation. Composites Science and Technology 133:23-32. https://doi.org/10.1016/j.compscitech.2016.07.012

166. Holden PA, et al. (2016) Considerations of environmentally relevant test conditions for improved evaluation of ecological hazards of engineered nanomaterials. Environmental Science \& Technology 50(12):6124-6145. https://doi.org/10.1021/acs.est.6b00608

167. Petersen EJ, et al. (2016) Quantification of carbon nanotubes in environmental matrices: Current capabilities, case studies, and future prospects. Environmental Science \& Technology 50(9):4587-4605. https://doi.org/10.1021/acs.est.5b05647

168. Selck H, Handy R, Fernandes TF, Klaine SJ, Petersen EJ (2016) Nanomaterials in the aquatic environment: An EU-USA perspective on the status of ecotoxicity testing, research priorities, and challenges ahead. Environmental Toxicology and Chemistry 35(5):1055-1067. https://doi.org/10.1002/etc.3385 
169. Mao L, Hu M, Pan B, Xie Y, Petersen EJ (2016) Biodistribution and toxicity of radio-labeled few layer graphene in mice after intratracheal instillation. Particle and Fiber Toxicology 13:7. https://doi.org/10.1186/s12989-016-0120-1

170. Zhao Q, et al. (2016) Sorption of 14C-labeled multiwall carbon nanotubes by humic acid and polymers: Role of sorbent properties. Carbon 99:229-237. https://doi.org/10.1016/j.carbon.2015.12.024

171. Toman B, Rosslein M, Elliott J, Petersen EJ (2016) Estimation and uncertainty analysis of dose response in an inter-laboratory experiment. Metrologia 53(1):S40S45. https://doi.org/10.1088/0026-1394/53/1/S40

172. Nelson BC, Johnson ME, Walker ML, Riley KR, Sims CM (2016) Antioxidant cerium oxide nanoparticles in biology and medicine. Antioxidants 5(2):15-1-21. https://doi.org/10.3390/antiox5020015

173. Nelson BC, et al. (2016) Emerging metrology for high-throughput nanomaterial genotoxicology Mutagenesis 32(1):215-232. https://doi.org/10.1093/mutage/gew037

174. Mao L, Liu C, Gu C, Petersen EJ (2016) Exposure of few layer graphene to limnodrilus hoffmeisteri modified the graphene and changes its bioaccumulation by other organisms. Carbon 109:566-574. https://doi.org/10.1016/j.carbon.2016.08.037

175. Pillai KV, et al. (2016) Environmental release of core-shell semiconductor nanocrystals from free-standing polymer nanocomposite films. Environmental Science: Nano 3:657-669. https://doi.org/10.1039/C6EN00064A

176. Jacobs DS, et al. (2016) Surface degradation and nanoparticle release of a commercial nanosilica/polyurethane coating under UV Exposure. Journal of Coatings Technology and Research 13(5):735-751. https://doi.org/10.1007/s11998$\underline{\text { 016-9796-2 }}$

177. Johnson ME, Montoro Bustos AR, Winchester MR (2016) Practical utilization of spICP-MS to study sucrose density gradient centrifugation for the separation of nanoparticles. Analytical and Bioanalytical Chemistry 408(27):7629-7640. https://doi.org/10.1007/s00216-016-9844-x

178. El Hadri H, Petersen EJ, Winchester MR (2016) Impact of correction for instrument sensitivity drift on nanoparticle size measurements by single particle ICP-MS. Analytical and Bioanalytical Chemistry 408(19):5099-5108. https://doi.org/10.1007/s00216-016-9397-z

179. Louie SM, et al. (2016) Photochemical transformations of thiolated polyethylene glycol thiol coatings on gold nanoparticles. Environmental Science: Nano 3(5):1090-1102. https://doi.org/10.1039/C6EN00141F

180. Mortimer M, Petersen EJ, Buchholz BA, Orias E, Holden PA (2016) Bioaccumulation of multiwall carbon nanotubes in Tetrahymena thermophile by direct feeding or trophic transfer. Environmental Science \& Technology 50(16):8876-8885. https://doi.org/10.1021/acs.est.6b01916 
181. Hanna SK, et al. (2016) Design and sensitivity testing of a Caenorhabditis elegans nanoecotoxicity assay. Environmental Science: Nano 3:1080-1089. https://doi.org/10.1039/C6EN00105J

182. Mortimer M, Petersen EJ, Buchholz BA, Holden PA (2016) Separation of bacteria, protozoa and carbon nanotubes by density gradient centrifugation. Nanomaterials 6(10):181-1-21. https://doi.org/10.3390/nano6100181

183. Ma C, et al. (2016) Defense mechanisms and nutrient displacement in arabidopsis thaliana upon exposure to $\mathrm{CeO}_{2}$ and $\mathrm{In}_{2} \mathrm{O}_{3}$ nanoparticles. Environmental Science: Nano 3(6):1369-1379. https://doi.org/10.1039/C6EN00189K

184. Sun J, et al. (2017) Biophysical characterization of functionalized titania nanoparticles and their application in dental adhesives. Acta Biomaterialia 53:585597. https://doi.org/10.1016/j.actbio.2017.01.084

185. Lu K, et al. (2017) Biological uptake, distribution and depuration of radio-labeled graphene in adult zebrafish: Effects of graphene size and natural organic matter. ACS Nano 11(3):2872-2885. https://doi.org/10.1021/acsnano.6b07982

186. Nguyen T, et al. (2017) Impact of UV irradiation on multiwall carbon nanotubes in nanocomposites: formation of entangled surface layer and mechanisms of release resistance. Carbon 116:191-200. https://doi.org/10.1016/j.carbon.2017.01.097

187. Johnson ME, et al. (2017) Separation, sizing, and quantitative analysis of engineered nanoparticles in an organism model using inductively coupled plasma mass spectrometry and image analysis. ACS Nano 11(1):526-540. https://doi.org/10.1021/acsnano.6b06582

188. Deng Y, et al. (2017) Multiple method analysis of TiO2 nanoparticle uptake in rice (Oryza sativa L.) plants. Environmental Science \& Technology 51(18):1061510623. https://doi.org/10.1021/acs.est.7b01364

189. Bjorkland R, Tobias D, Petersen EJ (2017) Increasing evidence indicates low bioaccumulation of carbon nanotubes. Environmental Science: Nano 4:747-766. https://doi.org/10.1039/C6EN00389C

190. Elliott JT, et al. (2017) Toward achieving harmonization in a nano-cytotoxicity assay measurement through an interlaboratory comparison study. Altex 34(2):201218. https://doi.org/10.14573/altex.1605021

191. Saheli PT, Rowe RK, Petersen EJ, O'Carroll DM (2017) Diffusion of multiwall carbon nanotubes (MWCNTs) through an HDPE geomembrane. Geosynthetics International 24(2):184-197. https://doi.org/10.1680/jgein.16.00025

192. Sung L, et al. (2017) Kinetics of photodegradation and nanoparticle surface accumulation of a nanosilica/epoxy coating exposed to UV light. Journal of Coatings Technology and Research 14(4):893-902. https://doi.org/10.1007/s11998016-9911-4

193. Su Y, Petersen EJ, Mao L (2017) Colloidal properties and stability of aqueous suspensions of few-layer graphene: Importance of graphene concentration. Environmental Pollution 220:469-477. https://doi.org/10.1016/j.envpol.2016.09.089 
194. Nguyen T, et al. (2017) Impact of UV irradiation on multiwall carbon nanotubes in nanocomposites: formation of entangled surface layer and mechanisms of release resistance. Carbon 116:191-200. https://doi.org/10.1016/j.carbon.2017.01.097

195. Waissi-Leinonen GC, et al. (2017) Chironums riparius exposure to fullerenecontaminated sediment results in oxidative stress and may impact life cycle parameters. Journal of Hazardous Materials 322 Part A:301-309. https://doi.org/10.1016/j.jhazmat.2016.04.015

196. Louie SM, Gorham JM, Tana J, Hackley VA (2017) Ultraviolet photo-oxidation of polyvinylpyrrolidone (PVP) coatings on gold nanoparticles. Environmental Science: Nano 4:1866-1875. https://doi.org/10.1039/C7EN00411G

197. Liu J, Murphy KE, Winchester MR, Hackley VA (2017) Overcoming challenges in single particle inductively coupled plasma mass spectrometry measurement of silver nanoparticles. Analytical and Bioanalytical Chemistry 409:6027-6039. https://doi.org/10.1007/s00216-017-0530-4

198. Sims CM, et al. (2017) Redox-active nanomaterials for nanomedicine applications. Nanoscale 9(40):15226-15251. https://doi.org/10.1039/C7NR05429G

199. Calderón-Jiménez B, et al. (2017) Silver nanoparticles: Technological advances, societal impacts, and metrological challenges. Frontiers in Chemistry 5:6-1-26. https://doi.org/10.3389/fchem.2017.00006

200. Calderón-Jiménez B, Sarmanho GF, Murphy KE, Montoro Bustos AR, VegaBaudrit JR (2017) NanoUV-VIS: An interactive visualization tool for monitoring the evolution of optical properties of nanoparticles throughout synthesis reactions. Journal of Research of the National Institute of Standards and Technology 122:371-10. https://doi.org/10.6028/jres.122.037

201. Hsueh HC, et al. (2017) Kinetics of photodegradation and nanoparticle surface accumulation of a nanosilica/epoxy coating exposed to UV light. Journal of Coatings Technology and Research 14:893-902. https://doi.org/10.1007/s11998$\underline{016-9911-4}$

202. Atha DH, et al. (2017) Quantifying engineered nanomaterial toxicity: Comparison of common cytotoxicity and gene expression measurements. Journal of Nanobiotechnology 15:79-1-9. https://doi.org/10.1186/s12951-017-0312-3

203. Singh N, et al. (2017) Exposure to engineered nanomaterials: impact on DNA repair pathways. International Journal of Molecular Sciences 18(7):1515-1-15. https://doi.org/10.3390/ijms18071515

204. Pitkanen L, Montoro Bustos AR, Murphy KE, Winchester MR, Striegel AM (2017) Quantitative characterization of gold nanoparticles by size-exclusion and hydrodynamic chromatography, coupled to inductively coupled plasma mass spectrometry (SEC/ICP-MS and HDC/ICP-MS) and quasi-elastic light scattering (HDC/QELS). Journal of Chromatography A 1511:59-67. https://doi.org/10.1016/j.chroma.2017.06.064 
205. El Hadri H, Hackley VA (2017) Investigation of cloud point extraction for the analysis of metallic nanoparticles in a soil matrix. Environmental Science: Nano 4:105-116.

206. Hanna SK, et al. (2018) Agglomeration of Escherichia coli with positively charged nanoparticles can lead to artifacts in a standard Caenorhabditis elegans toxicity assay. Environmental Science \& Technology 52(10):5968-5978. https://doi.org/10.1021/acs.est.7b06099

207. El Hadri H, Louie SM, Hackley VA (2018) Assessing the interactions of metal nanoparticles in soil and sediment matrices-a quantitative analytical multitechnique approach. Environmental Science: Nano 5:203-214. https://doi.org/10.1039/C7EN00868F

208. Goodwin Jr DG, et al. (2018) Detection and quantification of graphene family nanomaterials in the environment. Environmental Science \& Technology 52(8):4491-4513. https://doi.org/10.1021/acs.est.7b04938

209. Ntim A, Norris S, Scott K, Thomas TA, Noonan GO (2018) Consumer use effects on nanoparticle release from commercially available ceramic cookware. Food Control 87:31-39.https://doi.org/10.1016/j.foodcont.2017.12.003

210. El Hadri H, Gigault J, Tan J, Hackley VA (2018) An assessment of retention behavior for gold nanorods in asymmetrical flow field-flow fractionation. Analytical and Bioanalytical Chemistry. https://doi.org/10.1007/s00216-018-1325-y

211. Tan J, et al. (2018) Surface modification of cisplatin-complexed gold nanoparticles and its influence on colloidal stability, drug loading, and drug release. Langmuir 34:154-163. https://doi.org/10.1021/acs.langmuir.7b02354

212. Mukherjee A, Hackley VA (2018) Separation and characterization of cellulose nanocrystals by multi-detector asymmetrical-flow field flow fractionation. Analyst 143:731-740. https://doi.org/10.1039/C7AN01739A

\section{Conference Proceedings}

1. Mansfield E, Geiss R, Fagan JA (2009) Methods for TEM analysis of NIST's singlewalled carbon nanotube Standard Reference Material. Proceedings of SPIE 7405: 74050A-1-11. https://doi.org/10.1117/12.825406

2. Pellegrin B, et al. (2009) Degradation and nanoparticle release of epoxy/nanosilica composites exposed to solar UV radiation. Proceedings Nanotech 2009, pp 94-97.

3. Nguyen T, et al. (2009) Network aggregation of CNT at the surface of epoxy/MWCNT composite exposed to UV radiation. Proceedings Nanotech 2009, pp 90-93.

4. Nguyen T, Pellegrin B, Gu X, Shapiro A, Chin J (2009) Degradation and nanofiller release of polymer nanocomposites exposed to ultraviolet environments. Proceedings of the 4th European Weathering Symposium, pp 149-162.

5. Nguyen T, et al. (2010) Direct evidence of nanoparticle release from epoxy nanocomposites exposed to UV Radiation. Proceedings Nanotech 2010, pp 724-727. 
6. Savelas A, Yu L, Bernard C, Nguyen T (2010) An analytical method to quantify silica nanoparticles accumulated on the surface of polymer composites exposed to UV radiation. Proceedings Nanotech 2010, pp 728-731.

7. Nguyen T, et al. (2010) Degradation and nanoparticle release of nanocomposite coatings exposed to UV radiation. Proceedings Coating Science International, pp 1621.

8. Nguyen T, et al. (2011) Fate of nanoparticles during life cycle of polymer nanocomposites. Physics Conference Series 340:012060-1-12. https://doi.org/10.1088/1742-6596/304/1/012060

9. Nguyen T, et al. (2011) Fate of graphene in polymer nanocomposite exposed to UV radiation. Physics Conference Series 304:012063-1-8.

10. Whelton AJ, Duncan TV, Koontz JL, Nguyen T (2011) Nanoparticle release from potable water infrastructure and food packaging polymer nanocomposites: current progress \& beyond. Proceedings Nanotech 2011, pp 505-508.

11. Whelton AJ, Nguyen T (2011) Contaminant migration from polymeric water pipes: US regulatory compliance implications. Proceedings American Water Works Association Conference 2011, pp 2842-2843.

12. Hume SL, Blacklock JL, Jeerage KM (2012) Functionalized nanoparticle release and distribution in PEG hydrogel delivery systems. Transactions of the $39^{\text {th }}$ Annual Meeting of the Controlled Release Society, 2 pp.

13. Taghizadeh-Saheli P, Rowe RK, Petersen EJ, O'Carroll DM (2013) Diffusive transport of multiwall carbon nanotubes through an HDPE geomembrane. Proceedings GéoMontréal 2013, 5 pp.

14. Weber KP, et al. (2013) Method for assessing the potential effects of nanoparticles and other emerging contaminants on the catabolic capabilities of microbial communities. Proceedings Micropol \& Ecohazard 2013, 5 pp.

15. Petersen EJ, Marquis BJ, Jaruga P, Dizdaroglu M, Nelson BC (2013) Quantitative assessment of nanoparticle induced oxidative DNA damage using isotope dilution mass spectrometry. Proceedings Nanotech 2013, pp 465-468.

16. Nelson BC, Petersen EJ, Tu X, Dizdaroglu M, Zheng M (2013) Oxidatively induced damage to DNA: Potential role of single-wall carbon nanotubes at the molecular level. Proceedings Nanotech 2013, pp 445-448.

17. Gorham JM, Nguyen T, Stanley DL, Bernard C, Holbrook Jr. RD (2013) Surface chemical transformations of UV irradiated silica-epoxy nanocomposites. Proceedings Nanotech 2013, pp 469-478.

18. Liu J, Murphy KE, MacCuspie RI, Winchester MR (2013) Optimizing instrument operation and data processing for single particle inductively coupled plasma mass spectrometry measurement of gold nanoparticles. Proceedings Nanotech 2013, pp $151-154$. 
19. Murphy KE, et al. (2014) Use of single particle inductively coupled plasma mass spectrometry to characterize a new silver nanoparticle reference material. Proceedings Nanotech 2014, pp 501-504.

20. Tien C-C, et al. (2014) Effects of temperature on surface accumulation and release of silica nanoparticles in an epoxy nanocoating exposed to UV radiation. Proceedings Nanotech 2014, pp 101-104.

21. Petersen EJ, et al. (2014) Multi-method analysis of multiwall carbon nanotube polymer nanocomposite samples after photodegradation. Proceedings Nanotech 2014, pp 75-78.

22. Rabb SA, Stanley D, Sung L, Nguyen T, Yu LL (2014) A study of nanosilica release from "weathered" polymer nanocomposites at different temperatures using ICP-OES. Proceedings Nanotech 2014, pp 82-85.

23. Johnson ME, Hanna SK, Petersen EJ, Nelson BC, Yu LL (2014) Using single particle ICP-MS as a tool for understanding metallonanoparticles transformation during nanotoxicity assays. Proceedings Nanotech 2014, pp 97-100.

24. Hsueh H-C, et al. (2017) Characterization of released particles on the surface of a weathered nanosilica/polyurethane coatings after abrasion. Proceedings Nanotech 2017, pp 355-358.

25. Goodwin Jr DC, et al. (2017) Performance and aging of graphene oxide/polyurethane nanocomposites. Proceedings NanoTech 2017, pp 341-344.

\section{NIST Publications}

1. Nguyen T, Sung L, Chin J, Persily A (2013) Characterization of airborne nanoparticle released from consumer products, NIST Technical Note 1787, 55 pp. https://doi.org/10.6028/NIST.TN.1787

2. Persily A, Lo LC, Nabinger S, Poppendieck D, Sung L (2014) Characterization of airborne nanoparticle released from consumer products. NIST Technical Note 1843, 36 pp. https://doi.org/10.6028/NIST.TN.1843

3. Sung L, Nguyen T, Persily A (2014) Nanoparticle released from consumer products: flooring nanocoatings and interior nanopaints. NIST Technical Note 1835, 78 pp. https://doi.org/10.6028/NIST.TN.1835

\section{Book Chapters}

1. Sung L, et al. (2009) Impact of nanoparticles on the scratch behavior of a polyurethane coating. ACS Symposium Series 1008: Nanotechnology Applications in Coatings, eds Fernando R, Sung L (ACS/Oxford University Press, Washington, DC), Chapter 12, pp 232-254. https://doi.org/10.1021/bk-2009-1008.ch012

2. Watson S, Forster A, Tseng I, Sung L (2009) Assessment of spectrophotometric assay methods on nanostructured pigments. ACS Symposium Series 1008: Nanotechnology Applications in Coatings, eds Fernando R, Sung L (ACS/Oxford University, Press Washington, DC), Chapter 17, pp. 349-372. https://doi.org/10.1021/bk-2009-1008.ch017 
3. Galyean A, Weinberg HS, Holbrook D, Leopold M (2012) Characterization of engineered nanoparticles in natural waters. Comprehensive Analytical Chemistry: Analysis and Risk of Nanomaterials in Environmental and Food Samples, eds Barceló D, Farré M (Elsevier, New York, NY), Vol. 59, pp 169-195. https://doi.org/10.1016/B978-0-444-56328-6.00005-0

4. Nguyen T, Wohlleben W, Sung L (2014) Mechanisms of aging and release from weathered nanocomposites. Safety of Nanomaterials Along Their Lifecycle: Release, Exposure, and Human Hazards, eds Wohlleben W, Kuhlbusch TAJ, Schnekenburger J, Lehr C-M (CRC Press, Boca Raton, FL), Chapter 14. https://doi.org/10.1201/b17774-18

5. Petersen EJ (2014) Ecotoxicological effects of carbon nanotubes: methodological issues and current research. Health and Environmental Safety of Nanomaterials, eds Njuguna J, Pielichowski K, Zhu H (Woodhead Publishing, Cambridge, UK), pp 175199.

6. Holbrook RD, Galyean AA, Gorham JM, Herzing A, Pettibone J (2015) Overview of nanomaterial characterization and metrology. Characterization of Nanomaterials in Complex Environmental and Biological Media, eds Baalousha M, Lead JR (Elsevier, Amsterdam, Netherlands), Chapter 2, pp 47-90. https://doi.org/10.1016/B978-0-08-099948-7.00002-6

7. Mansfield E (2015) Recent advances in thermal analysis of nanoparticles: methods, models and kinetics. Modeling, Characterization and Production of Nanomaterials: Electronics, Photonics, and Energy Applications, eds Tewary VK, Zhang Y (Woodhead Publishing, Cambridge, UK), Chapter 8, 1st Ed.,17 pp.

8. Johnston LJ, Mansfield E, Smallwood GJ (2017) Physicochemical properties of engineered nanomaterials. Metrology and Standardization for Nanotechnology: Protocols and Industrial Innovations, eds Mansfield E, Kaiser DL, Fujita D, Van de Voorde M (Wiley-VCH Verlag GmBH \& Co., Weinheim, Germany), pp 99-112. https://doi.org/10.1002/9783527800308.ch5

9. Mansfield E, Hartshorn R, Atkinson A (2017) Nanomaterial recommendations from the International Union of Pure and Applied Chemistry (IUPAC). Metrology and Standardization for Nanotechnology: Protocols and Industrial Innovations, eds Mansfield E, Kaiser DL, Fujita D, Van de Voorde M (Wiley-VCH Verlag GmBH \& Co., Weinheim, Germany), pp 299-305. https://doi.org/10.1002/9783527800308.ch18

10. Kaiser DL (2017) Standards from ASTM International Technical Committee E56 on Nanotechnology. Metrology and Standardization for Nanotechnology: Protocols and Industrial Innovations, eds Mansfield E, Kaiser DL, Fujita D, Van de Voorde M (Wiley-VCH Verlag GmBH \& Co., Weinheim, Germany), pp 269-278. https://doi.org/10.1002/9783527800308.ch15

11. Scott K, Pomar-Portillo V, Vázquez-Campos S (2017) Nanomaterials in textiles. Metrology and Standardization for Nanotechnology: Protocols and Industrial Innovations, eds Mansfield E, Kaiser DL, Fujita D, Van de Voorde M (Wiley-VCH 
Verlag GmBH \& Co., Weinheim, Germany), pp 559-572.

https://doi.org/10.1002/9783527800308.ch31

12. Nelson BC, Reipa V (2017) Analytical measurements of nanoparticles in challenging and complex environments. Metrology and Standardization for Nanotechnology: Protocols and Industrial Innovations, eds Mansfield E, Kaiser DL, Fujita D, Van de Voorde M (Wiley-VCH Verlag GmBH \& Co., Weinheim, Germany), pp 115-127. https://doi.org/10.1002/9783527800308.ch9

13. Roebben G, Hackley VA, Emons H (2017) Reference nanomaterials to improve the reliability of nanoscale measurements. Metrology and Standardization for Nanotechnology: Protocols and Industrial Innovations, eds Mansfield E, Kaiser DL, Fujita D, Van de Voorde M (Wiley-VCH Verlag GmBH \& Co., Weinheim, Germany), pp 307-322. https://doi.org/10.1002/9783527800308.ch19

14. Chang C-H, Su P-J, Liu BH, Watson SS, Sung L (2017) Effect of UV radiation on surface mechanical properties of nanoTiO2-acrylic urethane coatings. Service Life Prediction for Polymers and Plastics Exposed to Outdoor Weathering, eds White CC, White KM, Pickett JE (New York, NY, Elsevier), Chapter 14, pp 247-262.

\section{Books Edited}

1. Mansfield E, Kaiser DL, Fujita D, Van de Voorde M (2017) Metrology and Standardization for Nanotechnology: Protocols and Industrial Innovations, (WileyVCH Verlag GmBH \& Co., Weinheim, Germany) 594 pp. 


\section{Appendix D: Nano-EHS Program Protocols and Assays}

\section{NIST Nano-Measurement Protocols}

https://www.nist.gov/mml/nano-measurement-protocols

1. Taurozzi JS, Hackley VA, Wiesner MR (2012) Reporting guidelines for the preparation of aqueous nanoparticle dispersions from dry materials. NIST Special Publication 1200-1. Ver 2.1, 9 pp. http://dx.doi.org/10.6028/NIST.SP.1200-1

2. Taurozzi JS, Hackley VA, Wiesner MR (2012) Preparation of nanoparticle dispersions from powdered material using ultrasonic disruption. NIST Special Publication 1200-2. Ver 1.1, 15 pp. http://dx.doi.org/10.6028/NIST.SP.1200-2

3. Taurozzi JS, Hackley VA, Wiesner MR (2012) Preparation of a nanoscale $\mathrm{TiO}_{2}$ aqueous dispersion for toxicological or environmental testing. NIST Special Publication 1200-3. Ver 1.2, 11 pp. http://dx.doi.org/10.6028/NIST.SP.1200-3

4. Taurozzi JS, Hackley VA, Wiesner MR (2012) Preparation of nanoscale $\mathrm{TiO}_{2}$ dispersions in biological test media for toxicological assessment. NIST Special Publication 1200-4. Ver 1.1, 13 pp. http://dx.doi.org/10.6028/NIST.SP.1200-4

5. Taurozzi JS, Hackley VA, Wiesner MR (2012) Preparation of nanoscale $\mathrm{TiO}_{2}$ dispersions in an environmental matrix for eco-toxicological assessment. NIST Special Publication 1200-5rl. Ver 1.2, 12 pp. http://dx.doi.org/10.6028/NIST.SP.1200-5r1

6. Hackley VA, Clogston JD (2015) Measuring the size of nanoparticles in aqueous media using batch-mode dynamic light scattering. NIST Special Publication 1200-6. Ver 1.2, 14 pp. http://dx.doi.org/10.6028/NIST.SP.1200-6

7. Gorham JM, et al. (2015) Preparation of silver nanoparticle loaded cotton threads to facilitate measurement development for textile applications. NIST Special Publication 1200-8. Ver 1.0, 18 pp. http://dx.doi.org/10.6028/NIST.SP.1200-8

8. Davis CS, Woodcock JW, Gilman JW (2015) Preparation of multi-walled carbon nanotube dispersions in a polyetheramine epoxy for eco-toxicological assessment. NIST Special Publication 1200-9. Ver 1.0, 13 pp. http://dx.doi.org/10.6028/NIST.SP.1200-9

9. Gorham JM, Woodcock JW, Scott KC (2015) Challenges, strategies and opportunities for measuring carbon nanotubes within a polymer composite by X-ray photoelectron spectroscopy. NIST Special Publication 1200-10. Ver 1.0, 9 pp. http://dx.doi.org/10.6028/NIST.SP.1200-10

10. Petersen EJ (2015) Control experiments to avoid artifacts and misinterpretations in nanoecotoxicology testing. NIST Special Publication 1200-11. Ver 1.0, 7 pp. http://dx.doi.org/10.6028/NIST.SP.1200-11

11. Reipa V (2015) Reconstitution of $2 \mathrm{~nm}$ diameter Silicon Nanoparticles (RM8027) into aqueous solvents. NIST Special Publication 1200-12. Ver 1.0, 18 pp. http://dx.doi.org/10.6028/NIST.SP.1200-12 
12. Zook J, MacCuspie, R, Long SE, Petersen EJ (2015) Measurement of silver nanoparticle dissolution in complex biological and environmental matrices using UV/visible absorbance measurements. NIST Special Publication 1200-13. Ver 1.0, 6 pp. http://dx.doi.org/10.6028/NIST.SP.1200-13

13. Zook JM, MacCuspie RI, Elliott JT, Petersen EJ (2015) Reliable preparation of nanoparticle agglomerates of different sizes in cell culture media. NIST Special Publication 1200-14. Ver 1.0, 7 pp. http://dx.doi.org/10.6028/NIST.SP.1200-14

14. Sung L, Nguyen T (2015) Protocols for accelerating laboratory weathering and measurements of degradation of polymer-multiwalled carbon nanotube composites. NIST Special Publication 1200-15. Ver 1.0, 16 pp. http://dx.doi.org/10.6028/NIST.SP.1200-16

15. Scott K, Giannuzzi LA (2015) Strategies for transmission electron microscopy specimen preparation of polymer composites. NIST Special Publication 1200-16. Ver 1.0, 10 pp. http://dx.doi.org/10.6028/NIST.SP.1200-16

16. Vladár AE (2015) Strategies for scanning electron microscopy sample preparation and characterization of multiwall carbon nanotube polymer composites. NIST Special Publication 1200-17. Ver 1.0, 16 pp. http://dx.doi.org/10.6028/NIST.SP.1200-17

17. Nelson BC, Petersen EJ, Jaruga P, Dizdaroglu M (2015) GC/MS measurement of nanomaterial-induced DNA modifications in isolated DNA. NIST Special Publication 1200-18. Ver 1.0, 13 pp. http://dx.doi.org/10.6028/NIST.SP.1200-18

18. Nelson BC, Petersen EJ, Jaruga P, Dizdaroglu M (2015) GC-MS/MS measurement of nanomaterial-induced DNA modifications in isolated DNA. NIST Special Publication 1200-19. Ver 1.0, 13 pp. http://dx.doi.org/10.6028/NIST.SP.1200-19

19. Nelson BC, Petersen EJ, Jaruga P, Dizdaroglu M (2015) LC-MS/MS measurement of nanomaterial-induced DNA modifications in isolated DNA. NIST Special Publication 1200-20. Ver 1.0, 11 pp. http://dx.doi.org/10.6028/NIST.SP.1200-20

20. Murphy KE, Liu J-Y, Montoro Bustos AR, Johnson ME, Winchester MR (2015) Characterization of nanoparticle suspensions using single particle inductively coupled plasma mass spectrometry. NIST Special Publication 1200-21. Ver 1.0, 29 pp. http://dx.doi.org/10.6028/NIST.SP.1200-21

21. Underwood SJ, Gorham JM (2017) Challenges and approaches for particle size analysis on micrographs of nanoparticles loaded onto textile surfaces. NIST Special Publication 1200-22. Ver 1.0, 13 pp. https://doi.org/10.6028/NIST.SP.1200-22

22. Johnson ME, et al. (2017) Sucrose density gradient centrifugation for efficient separation of engineered nanoparticles from a model organism, Caenorhabditis elegans. NIST Special Publication 1200-24. Ver 1.1, 18 pp. https://doi.org/10.6028/NIST.SP.1200-24

23. Savelas AR, Yu LL, Jacobs DS, Nguyen T, Sung L (2017) Protocol for collecting and quantifying release from weathered epoxy-nanosilica coatings: Using a simulated rain method and inductively coupled plasma-optical emission spectrometry. NIST Special Publication 1200-25. Ver 1.0, 10 pp. https://doi.org/10.6028/NIST.SP.1200-25 
24. Cho TJ, Hackley VA (2018) Assessing the chemical and colloidal stability of functionalized gold nanoparticles. NIST Special Publication 1200-26. 13 pp. https://doi.org/10.6028/NIST.SP.1200-26

\section{NIST-NCL Assay Protocols}

Nanotechnology Characterization Laboratory (NCL), National Cancer Institute https://ncl.cancer.gov/resources/assay-cascade-protocols [accessed 2018 August 17].

1. Grobelny J, et al. (2009) Size measurement of nanoparticles using atomic force microscopy. NIST - NCL Joint Assay Protocol, PCC-6. Ver 1.1, 2009, 20 pp. [accessed 2018 July 3]. https://ncl.cancer.gov/sites/default/files/protocols/NCL_Method_PCC-2.pdf

2. Hackley VA, Clogston JD (2010) Measuring the size of nanoparticles in aqueous media using batch-mode dynamic light scattering. NIST - NCL Joint Assay Protocol, PCC-1. Ver 1.1, 22 pp. [accessed 2018 July 3]. https://ncl.cancer.gov/sites/default/files/protocols/NCL_Method_PCC-1.pdf

3. Bonevich JE, Haller WK (2010) Measuring the size of nanoparticles using transmission electron microscopy (TEM). NIST - NCL Joint Assay Protocol, PCC-7. Ver 1.1, 13 pp. [accessed 2018 July 3]. https://ncl.cancer.gov/sites/default/files/protocols/NCL_Method_PCC-7.pdf

4. Yu LL, Wood LJ, Long SE (2010) Determination of gold in rat tissue with inductively coupled plasma mass spectrometry. NIST - NCL Joint Assay Protocol, PCC-8. Ver 1.1, 21 pp. [accessed 2018 July 3]. http://nanolab.cancer.gov/NCL_Method_PCC-8.pdf

5. Yu LL, Wood LJ, Long SE (2010) Determination of gold in rat blood with inductively coupled plasma mass spectrometry. NIST - NCL Joint Assay Protocol, PCC-9. Ver 1.1, 20 pp. [accessed 2018 July 3]. http://nanolab.cancer.gov/NCL_Method_PCC-9.pdf

6. Pease III LF, Tsai D-H, Zangmeister RA, Winchester MR, Tarlov MJ (2010) Analysis of gold nanoparticles by electrospray differential mobility analysis (ES-DMA). NIST NCL Joint Assay Protocol, PCC-10. Ver 1.1, 8 pp. [accessed 2018 July 3]. http://nanolab.cancer.gov/NCL_Method_PCC-10.pdf

7. Winchester MR (2010) Method for determination of the mass fraction of particlebound gold in suspensions of gold nanoparticles. NIST - NCL Joint Assay Protocol, PCC-11. Ver 1.1, 16 pp. [accessed 2018 July 3]. http://nanolab.cancer.gov/NCL_Method_PCC-11.pdf

8. Pratt KW (2010) Measuring the electrolytic conductivity of nanoparticle suspensions. NIST - NCL Joint Assay Protocol, PCC-12. Ver 1.1, 8 pp. [accessed 2018 July 3]. http://nanolab.cancer.gov/NCL_Method_PCC-12.pdf

9. Pratt KW (2010) Measuring the $\mathrm{pH}$ of nanoparticle suspensions. NIST - NCL Joint Assay Protocol, PCC-13. Ver 1.1, 8 pp. [accessed 2018 July 3]. http://nanolab.cancer.gov/NCL_Method_PCC-13.pdf 
10. Cleveland D (2010) Quantification of free and chelated gadolinium species in nanoemulsion-based magnetic resonance imaging contrast agent formulations using hyphenated chromatography methods. NIST - NCL Joint Assay Protocol, PCC-14. Ver 1.0, 24 pp. [accessed 2018 July 3]. http://nanolab.cancer.gov/NCL_Method_PCC14.pdf

11. Vladár AE, Ming B (2011) Measuring the size of colloidal gold nano-particles using high-resolution scanning electron microscopy. NIST - NCL Joint Assay Protocol, PCC-15. Ver 1.0, 20 pp. [accessed 2018 July 3].

http://nanolab.cancer.gov/NCL_Method_PCC-15.pdf 


\section{Appendix E: Nanoscale Reference Materials}

RM: Reference Material; SRM: Standard Reference Material; NP: nanoparticle; CNT: carbon nanotube

\begin{tabular}{|c|c|c|c|c|c|c|}
\hline $\begin{array}{l}\text { Material } \\
\text { Type }\end{array}$ & Identifier(s) & Form & $\begin{array}{l}\text { Reference } \\
\text { Property }\end{array}$ & $\begin{array}{l}\text { Nominal } \\
\text { Value }\end{array}$ & $\begin{array}{l}\text { Release } \\
\text { Date }\end{array}$ & $\begin{array}{l}\text { Total \# } \\
\text { Units } \\
\text { Sold* } \\
\end{array}$ \\
\hline \multirow{3}{*}{ gold NPs } & RM 8011 & \multirow{3}{*}{$\begin{array}{l}\text { in aqueous } \\
\text { suspension }\end{array}$} & \multirow{3}{*}{$\begin{array}{l}\text { mean } \\
\text { diameter }\end{array}$} & $30 \mathrm{~nm}$ & $12 / 17 / 07$ & 555 \\
\hline & RM 8012 & & & $60 \mathrm{~nm}$ & $12 / 17 / 07$ & 615 \\
\hline & RM 8013 & & & $100 \mathrm{~nm}$ & $12 / 17 / 07$ & 613 \\
\hline $\mathrm{TiO}_{2} \mathrm{NPs}$ & SRM 1898 & dry powder & $\begin{array}{l}\text { specific } \\
\text { surface } \\
\text { area }\end{array}$ & $55 \mathrm{~m}^{2} / \mathrm{g}$ & $6 / 14 / 12$ & 118 \\
\hline silver NPs & RM 8017 & freeze-dried & \begin{tabular}{|l|}
$\begin{array}{l}\text { mean } \\
\text { diameter }\end{array}$ \\
\end{tabular} & $75 \mathrm{~nm}$ & $12 / 6 / 14$ & 67 \\
\hline silicon NPs & RM 8027 & $\begin{array}{l}\text { in toluene } \\
\text { suspension }\end{array}$ & $\begin{array}{l}\text { mean } \\
\text { diameter }\end{array}$ & $2 \mathrm{~nm}$ & $2 / 4 / 14$ & 9 \\
\hline \multirow{2}{*}{$\begin{array}{l}\text { single-wall } \\
\text { CNTs }\end{array}$} & SRM 2483 & dry soot & $\begin{array}{l}\text { mass } \\
\text { fraction }\end{array}$ & $\begin{array}{l}\text { impurity } \\
\text { elements }\end{array}$ & $11 / 14 / 11$ & 62 \\
\hline & RM 8281 & $\begin{array}{l}\text { in aqueous } \\
\text { suspension }\end{array}$ & length & $\begin{array}{l}\text { "long", } \\
\text { "medium", } \\
\text { "short" }\end{array}$ & $7 / 9 / 13$ & 15 \\
\hline $\begin{array}{l}\text { multiwall } \\
\text { CNTs }\end{array}$ & SRM 2484 & dry soot & $\begin{array}{l}\text { mass } \\
\text { fraction }\end{array}$ & $\begin{array}{l}\text { impurity } \\
\text { elements }\end{array}$ & $6 / 1 / 17$ & 0 \\
\hline
\end{tabular}

*As of July 2018 